\title{
1 \\ The aesthetic turn after Stalin
}

In October 1967 readers of the journal Dekorativnoe Iskusstvo SSSR were probably surprised to find that the latest issue lacked its usual table of contents and was mostly devoid of text. Instead, they were confronted with forty-five pages of high-quality colour and black-and-white images of objects produced in the Soviet Union over the past five decades since its founding. This is how the journal's editors - made up of decorative artists, designers, critics and philosophers - chose to celebrate the jubilee of the October Revolution, joining the chorus of festivities organised all over the country in 1967. The editorial, appropriately entitled 'Glory to the 50th Anniversary of the Great October Socialist Revolution', explained that they wanted to 'give the floor to the wordless yet eloquent witnesses to our history, the products of the creative spirit of artists'. ${ }^{1}$

The following pages contained no text, only the images of the 'witnesses': monuments to the Soviet Constitution, Karl Marx and Jean-Paul Marat, built in 1918-19 in Moscow according to the Lenin Plan of Monumental Propaganda; a 1920 porcelain saucer, 'Red Baltic Fleet', decorated with the figure of a revolutionary sailor; the 1935 post-constructivist pavilion of the Moscow metro station Red Gates by the avant-garde architect Nikolai Ladovskii; an ensemble of traditional clay toys produced by Tajik, Uzbek and Russian craftsmen in 1960-61; the 1967 memorial to the victims of Nazism on the site of the labour camp Salaspils (Latvia); a 1967 pulegoso $^{2}$ glass vase made by Moscow artists; a selection of late 1920s textile patterns with industrial motifs; the interior of the Soviet Pavilion at Expo 1967 in Montreal; a decorative painting of a peacock by a village craftsman from the Kiev region; the recently finished high-rise building of the COMECON headquarters on New Arbat Street in Moscow; and many more (plate 1). The gallery concluded with a black-and-white photo of a 1920s statue of Lenin in Batumi, Georgia, resolutely facing the opposite page, coloured a pure, simple red. 
To today's observers, the image gallery is striking because of the eclecticism of themes, types, scales and techniques within it. Its principles appear opaque. In a way, they can be considered similar to those of Jorge Luis Borges's Chinese Encyclopaedia, famously invoked by Michel Foucault in the preface to The Order of Things, in which the reader faces the 'oddity of unusual juxtapositions'. What was the reason for placing side-by-side a war memorial, a porcelain cup, the interior of a youth café and a monument to Lenin? The simple answer would be that they were all produced in the Soviet Union, but this does not explain precisely why these objects in particular were chosen. It also does not explain the slightly mixed chronology (interchanging objects from the 1920s and 1960s) or the conspicuous absence of anything from the late 1930s to the 1950s. The question remains: what was the logic behind this order of things?

I suggest that the commonality between these images, which would have been immediately comprehensible to the journal's readers, was a particular aesthetic that gradually emerged in the Soviet Union after Stalin's death in 1953 and became pronounced by the late 1960s. I do not use 'aesthetics' as it is used in art theory or in the philosophy of art. Instead, I interpret aesthetics in a broader sense, one first proposed by Jacques Rancière, as 'a specific regime for identifying and reflecting on the arts: a mode of articulation between ways of doing and making, their corresponding modes of visibility, and possible ways of thinking about their relationships'. ${ }^{3}$ This new aesthetics came to replace the Stalinist regime of arts, which, following Rancière, can be deemed representative, that is, it adhered to a hierarchy of genres and subject matter and privileged speech over visibility. ${ }^{4}$ Within such a representative regime, the publication of the image gallery in Dekorativnoe Iskusstvo SSSR discussed above would have been unthinkable. Even the idea of a special journal just for decorative art would have been impossible. Dekorativnoe Iskusstvo SSSR did not exist until December 1957. Although the rhetoric and meanings of art criticism changed throughout the Stalin era, text always overshadowed visual imagery. For example, the article 'Thirty-Five Years of Soviet Art' by the president of the Soviet Academy of Arts Aleksandr Gerasimov, published in the official art journal Iskusstvo in November 1952, included very few images - only figurative painting and heroic sculptures. This was accompanied by a long narrative glorifying the triumph of socialist realism with an abundance of references to the great works of Lenin and Stalin. The images were only illustrations for the text. By contrast, in the October 1967 issue of Dekorativnoe Iskusstvo SSSR the text was reduced only to captions, making the images the primary carriers of the ideals of the Revolution. In other words, the images themselves represented the new, post-Stalin order of things.

The aesthetic regime of arts emerged in Soviet Russia in place of the representative one in the 1950s, peaked in 1960, and took on a more or less clear shape by the start of the 1960s. I call this process the aesthetic 
turn and consider it the cornerstone of post-Stalin Soviet modernism. The aesthetic turn was not just a return to the avant-garde or to the cultural pluralism of the 1920s, which had not been limited to the avant-garde. Rather, it was a gradual formation of new concepts, largely driven by people who had been connected to avant-garde movements in the 1920s. Therefore, the aesthetic turn refers to change without neglecting the importance of continuity. This chapter offers an overview of the key concepts of the new aesthetic regime of arts and provides background for my analysis of late socialist objects in the following chapters. In the overview I describe the following concepts: first, realism as a specific quality of things, not depictions of them; second, contemporaneity as a measure of the social relevance of an object; and third, taste as a tool for constructing social hierarchies and probing the limits between authenticity and appearance.

\section{Realism reconsidered}

In the history of art, the Stalin era in the Soviet Union is widely known as the period of socialist realism. According to the 1934 formulation of the chief Party ideologist Andrei Zhdanov, presented at the First All-Union Congress of Soviet Writers, socialist realism was not a style but a method of art-making (its eclectic character is often emphasised), ${ }^{5}$ a working method obligatory for artists in all fields. Despite its totalising rhetoric, socialist realism was not monolithic. In fact it had different faces depending on the artist, the genre and the medium. ${ }^{6}$ It did not even preclude artistic individuality; this was exemplified by the cases of the painters Aleksandr Deineka and Aleksandr Laktionov, both of whom were incorporated into the framework of socialist realism despite being vastly different artists. ${ }^{7}$ Nonetheless, regarding visual arts, socialist realism had a common feature: according to the official formula, an artist was expected to portray reality 'in its revolutionary development' ${ }^{\text {- }}$ that is, to visualise the state's promises by depicting recognisable life forms in the desired manner.

Formally, socialist realism remained the only permitted artistic method until perestroika. However, with the changes in cultural policies after Stalin, including the rise of decorative art and the emergence of the design profession, the notion of socialist realism could not remain the same. To fulfil the modern socialist material culture, the notion of socialist realism had to be updated. What follows is an overview of theoretical and practical attempts to adapt socialist realism to what Susan E. Reid calls the 'Khrushchev Modern'9 - the move towards the mass industrial production of commodities and to mass consumption.

In the early 1950s decorative artists gave topicality priority over materiality. For example, students of the newly established schools of art and industry were expected to render the powerful, positive image of a contemporary - a type. This was an unavoidable requirement of Stalinist 
artistic policy, which had spread from literature to all the visual arts. The intention was to portray the 'correct type' of Soviet personality, a model for identification, while all the decorative techniques - use of light, colour, material, texture - were just means to achieve this. This is evident in the Leningrad critic V. Kalinin's review of the 1953 graduate projects of the Mukhina School. He praised the works that had received the highest grades for the skilful adaptation of their materials to the subject matter. According to this logic, material such as stained glass was just a tool for creating figurative imagery in architecture. At that time, the Moscow Research Institute of Decorative and Applied Art was developing new techniques for decorating stained glass, such as etching, engraving and counter-reliefs. According to Kalinin, these innovations enabled the artist to 'render more adequately and realistically life-affirming images of our reality, first of all, images of Soviet people in the fullest of their spiritual wealth'. He used two examples to illustrate his point:

The stained glass by the student V. Statun, depicting a girl collective farmer labouring, is carried out in a gold-yellow, sunny range of colours, which perfectly expresses its ideological content - free labour in our country as a source of joy and abundance. The stained glass is rich in chiaroscuro transitions without tinting $[\ldots]$

A subtle mastery of various techniques is demonstrated by Galazova in her stained glass 'Abundance of Ukraine', rich and bright in colour, designed for the Kharkov bus station. ${ }^{10}$

What is noteworthy here is not the heroic and celebratory imagery - a universal and predictable feature of late Stalinist art - but the attention given to the very specific, technical skills of the artists in the official critique. The inherent qualities of glass were connected (or, rather, subordinated) to the Soviet symbolism of cheerfulness, prosperity and abundance. The traditional type of decorative art was used in a new way: instead of producing the transcendent, supernatural imagery of saints in Gothic churches, stained glass now generated expressly earthly, hyper-natural personifications of Soviet ideals: 'free labour', 'abundance', etc. Ironically, the transparency of glass was also intended to produce a divine effect - the true fulfilment of a miracle, according to Soviet mythology. ${ }^{11}$

Likewise, students in artistic ceramics employed traditional forms to render distinctly Soviet content. Kalinin marked a pair of porcelain vases with the portraits of Lenin and Stalin (co-created by S. Bogdanova and K. Kosenkova) as the most important works of the 1953 graduates of the Mukhina School. In Kalinin's description, the vases' 'well-composed and sublime' forms referred to antique amphorae, while their bodies served as ground for the subtly painted portraits in frames of 'festive gold ornament' - perfectly in tune with the classicist sympathies inherent to socialist realism. As properly 'orthodox' artworks, the vases were exhibited in the State Hermitage Museum. ${ }^{12}$ 
Yet one should not overestimate the role of figurative elements in early 1950s decorative art. Although encouraged, realistic depiction was avoidable. First, purely ornamental decoration was justified if it was based on folk art, which made it art of the 'people' and 'democracy'. Second, not all realistic motifs were praised indiscriminately; that was reserved for art that the critics considered masterfully adapted to its medium. Moreover, the critique of 'easel style' (stankovizm) in applied and decorative art was present as early as 1953 and became stronger with the unfolding of Khrushchev's Thaw. A heroic, perfectly socialist subject matter, even when combined with an artist's supreme skill, was not enough to guarantee a successful result: the medium also had to be taken seriously.

In the spring of 1955 Iskusstvo, an official journal of the Artists' Union of the USSR, published an article written by the prominent art historian Aleksandr Saltykov. The article argued that decorative art requires a different methodology of depiction compared to easel art. Saltykov asserted that the form, proportionality and naked beauty of an object should serve as the basis for decoration, and this decoration should not be a depiction with atmospheric perspective. Therefore, 'of primary importance are the foreground, the clear, expressive contours, and the rhythmically arranged and harmonised silhouettes'. ${ }^{13}$ Furthermore, Saltykov reasoned that decorative art was not psychological: the decorative artist chooses and arranges real phenomena 'with great freedom', and sometimes even selects only certain elements of those phenomena. Decorative compositions can be very close to illusory depiction but can also sufficiently differ from it. Additionally, 'one of the indispensable qualities of a decorative artist is wide and daring fantasy'. The article clearly stated that socialist realism was by no means a universal method and that it could even become kitsch and banal when misapplied. Saltykov meticulously listed the atrocities produced by overly ardent followers of realist principles:

A glass factory in Diat'kovo [a town in the Briansk region] produces flower vases out of opal glass, with ugly forms, with the depiction of a monumental statue, 'A tractor driver and a woman collective farmer', copied from a photo. The depiction is integrated neither with surrounding ornaments nor with the object itself, and these vases can serve as examples of bad taste. The Leningrad factory of lead glass tableware fabricates similar vases, depicting the monument to [General Aleksandr] Suvorov, almost unrecognisable and also unrelated to the vases' shapes. 'Mosshtamp' factory produces metal cigarette cases with the bas-relief depiction of three epic heroes Ifrom the famous 1898 painting] by [Viktor] Vasnetsov. Not much remained from the heroes [ot bogatyrei malo chto ostalos'], their distorted figures are in disharmony with the case, and the object indeed looks defective. ${ }^{14}$

Further examples included clumsy adaptations of famous scenes from nineteenth-century Russian paintings for the decoration of powder cases, purses, writing pads and lacquer boxes. 
About a year later, Iskusstvo published a polemical article by the young Leningrad philosopher and art historian Moisei Kagan entitled 'On the Specificity and Essence of Decorative-applied Art'. ${ }^{15}$ Everywhere except in the title, Kagan preferred to use the term 'applied art' over 'decorative' in order to dissociate it from decoration, which he considered superficial, holding 'decorative' to be a pejorative term. While he disagreed with Saltykov on certain points, Kagan also contended that applied art is not illusory by nature and does not represent anything, but rather fulfils concrete practical needs. In this respect, it is akin to architecture. Of the two aspects of architecture and applied art - practical and what Kagan calls 'ideological-aesthetic' - the former is more important. Artistic content and aesthetic form - the elements fulfilling ideological function - should be subordinated and applied to the practical function, Kagan argued. Thus, he concluded, architecture is also an applied art and only distinct because of its monumental character. ${ }^{16}$ Commenting on this same article at a professional meeting several months later (shortly after the famous XXth Party Congress, where Khrushchev denounced Stalin's repressions), Kagan presented his vision of 'everyday' socialist realism:

I believe that one of the main principles of applied art and one of the requirements of socialist realism is a specific simplicity, concision, and modest use of decorative means, which are opposed, on the one hand, to the decorativist style that until recently prevailed in our architecture and applied art, and, on the other hand, to the asceticism of Constructivism that absolutely rejected any use of decorative means. ${ }^{17}$

Here, Kagan skilfully used forms of authoritative discourse to update the notion of socialist realism - mutatis mutandis, which could be applied to state socialism, in the spirit of de-Stalinisation. His goal was to correct the misdeeds of the recent past, arguing against corrupt Byzantine grandeur and advocating for a return to the original Bolshevik ethos, but avoiding what he perceived as the avant-garde's asceticism. Stalinists and the 'ancients' of art were quick to respond.

The main counterattack came from Nina Iaglova, an established art critic. She objected that applied art is figurative, because it is always based on some recognisable motif, even if often indirectly. Iaglova illustrated this argument with slides showing ancient artefacts (pre-Scythian, Scythian, Egyptian and Russian artefacts of the seventeenth century): vessels resembling birds, tables with 'animal' legs, etc. ${ }^{18}$ The only two contemporary examples given by Iaglova were art pieces of late Stalinism: lacework 'Squirrels' (she did not mention the artist) and a machine-made wall carpet by the artist Eremeeva, 'The Feast of Harvest'. Both, I suggest, are examples of what can be called 'lyric' realism, which would soon come to be seen as Stalinist kitsch by decorative art reformers. Speaking of the 'Squirrels', Iaglova noted enthusiastically: 
This object is meant to live in our byt, to bring warmth and joy into our life. The artist achieves this impression through the theme of Russian nature, which, maybe, could be expressed in painting far more concretely; but applied art, [in particular] lace, has its own means, and we enjoy looking at this poetic image of Russian nature ... Every type of art has its own degree of closeness to nature, its own measure of conditionality. ${ }^{19}$

This kind of realism, with its references to warmth, enjoyment and poetic feeling, can be termed 'lyric', as a counterpart to the 'epic' realism of celebratory glass, ceramic or textile tapestries.

In response, Kagan argued that an image (obraz) should not be confused with a portrayal (izobrazheniie). He added that all of the arts are image-bearing (obraznye) in their own way but that not all of them are figurative (izobrazitel'nye). ${ }^{20}$ Kagan ultimately rejected both 'epic' and 'lyric' versions of socialist realism, offering a 'practical' one instead: 'I love art, but a chair is made for sitting, a cup for drinking, clothes for wearing, and architecture for living. And when this elementary and prosaic fact is forgotten, there appear various aesthetically unpleasant things.' This indicates that for Kagan not only does form follow function, as Louis Sullivan put it, but artistic image follows function. ${ }^{21}$

A particularly interesting instance of the post-Stalin reconsideration of realism was made by the art critic Aleksandr Chekalov at a lecture in the decorative-applied art section of the Moscow branch of the Artists' Union in January 1959. Like Kagan, Chekalov belonged to a young generation of art critics (he was 31 at the time). His lecture, titled 'Peculiarities of Reflecting Life in Artistic-Industrial Objects', outlined the principles and objectives of emerging Soviet design. At the start, Chekalov proposed three major questions for discussion:

1 What are artistic-industrial items - art or non-art? If [they are] art, can they be ascribed to visual art? Where is the border between the artistic and the non-artistic? [My emphasis.]

2 Can the term 'realism' be used regarding decorative-applied art? If yes, how should we deal with the notions of typicality [tipichnost'], artistic image and so on? Because, you know, we should speak of the standard [tipovoi] [items], but this is a different matter.

3 If we speak of realism, should we then speak of the opposite notions formalism or abstractionism? Can we, for example, call geometrically shaped items of decorative ${ }^{22}$ art 'abstract'? ${ }^{23}$

Chekalov's agenda can be viewed as ranging from the general philosophical question 'Where is the border between the artistic and the nonartistic?' to the more particular problem of resolving the canonical vision of realism with the practical tasks of industry. The latter, he emphasised, was an urgent problem for Soviet art theory.

In order to solve the conundrum of the unlikely marriage of realism and decorative and 'industrial' art, Chekalov proposed a 'revisionist' 
theory of realism. His explanation sounds like an argument against Kant's theory of disinterested aesthetic judgement:

However ingenuously we perceive this or that object of decorative art - a rug, a statuette, an architectural decoration, wallpaper, furniture, a toy - we always mentally evaluate it. The basis of this evaluation is our general impression of this object, depending on whether we call it beautiful or not beautiful. Even the most superficial analysis makes us realise that we associate the beautiful with the living. Our eye distinguishes between 'vibrant' and 'dead' forms, between colours and lines [which are] intensive, taut, or, in contrast, languid. We always prefer bold, melodious, rich details and reject those that look dry, stiff and stunted. The vibrant for us is a kind of a synonym for the artistic. $^{24}$

Evidently, the speaker downplays the concept of 'realism' by replacing it with the notion of vibrancy (zhivost') and equating it with beauty. This notion is convenient, first, because it corresponds to the Soviet cult of health, cheerfulness and physical culture, and, second, because it is flexible enough to extend to stylised figurative and even non-figurative images. Thus, Chekalov argued that the characters in Greek vase painting or the grotesque figures of birds and animals that decorate ancient and folk vessels are no less vibrant than highly realistic art forms. Furthermore, he highlighted the vibrancy of geometric objects, ornaments and even 'monochromatic yet texturally expressive fabrics' ${ }^{25}$ Note the parallel with Iaglova's reasoning: if for her the animalistic forms of ancient artefacts were an argument in favour of figurativeness, for Chekalov they were valuable because of their stylised character, their particular abstraction from nature. Objects with very naturalistic shapes are often the worst, he argued. Naturalism is opposed to the 'vibrant beauty' that only bears a slight resemblance to reality; the viewer needs to recognise this resemblance and, therefore, to be attentive rather than passive in the act of perception.

While his critique of naturalism in painting corresponded to the official Soviet art theory of the early $1950 \mathrm{~s},{ }^{26}$ Chekalov's talk is notable because of how he implicitly defended abstraction: 'Even simple checks and chequers can be extremely "vivid" and full of artistic content, but they can also be dry, rigid, and "dead" like a technical drawing. It depends on intention and implementation. ${ }^{27}$ Chekalov argued that in art any close resemblance to life is deadly and repulsive, explaining that

We like the vibrant, the vital, but our taste requires that this vibrant, sensible, concrete become more abstract, lose its immediate concreteness, in a way, die as a concrete phenomenon. Then it would re-emerge in a completely different quality - as something absolutely unlike the habitual forms, built according to different principles. And only such a converted form is perceived as 'vibrant'; it suddenly gives us a new wonderful idea of the whole sensible, concrete, genuine life in all its beauty and variety. ${ }^{28}$ 
To justify this odd claim that the living should symbolically die and be resurrected in art, Chekalov relied on Marx's authority, but, peculiarly, that of a young Marx. Evidently, Marx's 1844 'Economic and Philosophical Manuscripts', particularly the part on alienated labour, became the most important point of reference for the generation of art critics during the Thaw. Special attention was given to the passage where Marx compares production processes between the animal and human world. While the animal produces only according to the immediate needs of itself or of its young, human beings can also produce 'free of physical need'; if the animal builds according to the standard of its species, a human being creates 'according to the laws of beauty'. Thus, humans' production is creative: it is a means of self-production 'not only intellectually, as in consciousness, but also actively in a real sense' as humans 'see themselves in a world they made'. ${ }^{29}$ Drawing on this point, Chekalov portrays art objects as a 'real product of conscious human labour', as a human being's self-expression with the spiritual dimension, including one's aesthetic views. ${ }^{30}$ Consequently, any human-made - or for that matter humandesigned and machine-made - object is an expression of real life and real creative labour. We evaluate objects of 'everyday art' (bytovogo iskusstva) by human measure, and therefore good objects are those that correspond to our ideas of convenience and beauty alike, concluded Chekalov, anticipating Soviet designers' obsession with ergonomics. ${ }^{31}$ From precisely this perspective, he appreciated folk art: its forms are organic and functionally justified. ${ }^{32}$

Further, Chekalov raised the problem of contemporary industrial production in relation to individuality. He admitted that 'the image of objects gradually becomes more and more general, that is to say, international. It more and more shows an abstract person, a human being as such ... Material culture knows no borders. ${ }^{33}$ This was a progressive argument for 1959, devoid of the usual reservations about the irreconcilability between socialist and capitalist values. However, what bothered Chekalov was not the danger of bourgeois consumerism but the threat to artistic individuality. He advocated researching better intrinsic qualities of materials, varying the treatments of surface, and creative uses of colour as ways of reducing such a threat. He described diverse qualities of industrially produced objects in a strikingly picturesque language:

Mass in the ready article is already not just a quantity of material but also a certain quality of a three-dimensional form: monumentality or fragility, lightness, completeness or openness and so on. The borderline of mass is not only the boundary of volume, but also an artistically found contour. The line itself becomes expressive - not just straight or curved, but flexible or restless, rhythmic or melodic. All the elements of form appear as if in the endless clash and movement and at the same time in harmonic coordination and unity. It is precisely this that we perceive as 'vibrant' in the best items of everyday art. ${ }^{34}$ 
This passage is noteworthy for two reasons. First, there is virtually no official cliché and no trace of authoritative discourse. Second, there is a clear (even if unintentional) echoing of the prominent art historian Nikolai Punin's description of Vladimir Tatlin's famous Monument to the Third International in 1919:

The form wants to overcome the matter, the force of gravitation; the force of resistance is big and massive; straining the muscles, the form seeks for emancipation along the most resilient and dynamic lines the world knows - the spirals. They are full of movement, striving, running, and they are tight like creative will and strained muscle. ${ }^{35}$

Just like the two counter-spirals of Tatlin's tower, the elements of form in Chekalov's 'perfect object' are in constant conflict and movement. Chekalov's organic metaphor is reminiscent of Punin's portrayal of the tower as a Promethean man, and, more broadly, reminiscent of the avantgarde obsession with drawing parallels between the organic world and industrial art. ${ }^{36}$

Finally, Chekalov forecast two ideas that would become very popular among Soviet designers a decade later - the design of environments and research on consumers' opinions. First, he claimed that a properly skilled and dedicated applied artist could humanise not only a single object of his or her making, but 'the whole sphere of activity related to this object'. Thus, a gunsmith does not just produce a rifle but 'organises the entire process of hunting', while 'sometimes human life depends on the form of his items'. Similarly, a tailor not only fits the seams of a piece of clothing, but is also responsible for making the client a better person by giving him or her a proper outfit. The same applies to the designer of a pavilion, a bus, a canteen. ${ }^{37}$ Second, according to Chekalov, the humanism of this new art lay in its openness, allowing a consumer to actively participate in its making through creating ensembles of interior, dress and so on. Notably, this explanation of humanism has a didactic note: 'every person must be an artist, must have an active artistic taste'. ${ }^{38}$ Therefore, when being invited to participate in the creative process, an imagined consumer is simultaneously pressed to accept the standards of taste established by the experts. In his concluding remarks, Chekalov urged artists to 'break the customs' and reflect in their art the 'new pulse of life', equating realism with functionality and feasibility, and formalism, conversely, with pretentiousness and uselessness. ${ }^{39}$

This argument provoked by Chekalov's concept of vibrancy was in itself vibrant. Some colleagues repudiated his reconceptualisation of formalism. Maria Nazarevskaia reminded Chekalov of the danger attached to abstract artworks that had been exhibited in Moscow during the International Youth Festival in 1957 and that were currently being shown at the exhibition 'Art of Socialist Countries' in the Manege exhibition hall. ${ }^{40}$ She argued 
that many artists' turn to the West as a source of fashion was simply due to a fear of seeming boring. Nazarevskaia went so far as to compare the adoption of geometric patterns in west European design to the widespread use of the swastika in Europe as a visual symbol of Nazi propaganda in the 1930s (a strange position from a Vkhutein graduate, whose textile patterns of the 1930s were based on highly stylised human figures and objects). ${ }^{41}$

However, there were sympathisers with Chekalov too: art historian Sergei Temerin noted that nature itself contains abstraction to some extent, and is thus appropriate for useful artworks. Pointing to the art exhibited in the room where the meeting took place, Temerin remarked: "There is a rug, it is pictorial, but if a contemporary artist, a Soviet artist, exhibited a picture like this, he would be torn into pieces for showing pure formalism. ' ${ }^{42}$ The artist Grigorii Zamskii claimed that current ideas of realism and decoration were outdated. They were too narrow and reductionist:

The point is that if we look at all our fabrics, we will see virtually the same motifs everywhere, repeated in endless variations - these will be geometric, animalistic or floral ornaments. But our world is much richer. When a contemporary artist, in particular a Western artist, starts reflecting on today's world on a broader scale, it seems unusual at first, and many think that it is nonrealistic. Currently I am working on decorating the pavilion 'Science' [for the All-Union Exhibition of People's Economyl, and when I encounter drawings and photos of micro-organisms, I see there a lot of amazing motifs for textile patterns. Take various sections that we can see through the microscope; take animal organisms, some molluscs or shells - these are amazing things, but we do not see and do not repeat them [in our patterns]. ${ }^{43}$

Zamskii questioned the ideological dichotomy of 'realism versus abstractionism': the abstract can also be organic, and therefore also realistic.

Although the idea of vibrancy per se did not generate a clear-cut artistic trend in late Soviet art, it nonetheless offered the possibility of criticising the principles of new Soviet modernism that were being formed in the late 1950s. This critical view, in turn, affected actual artistic production, which diverged from the strict requirements of standardisation and utility. Although far from Jane Bennett's post-anthropocentric notion of vibrancy ${ }^{44}$ the post-Stalin discussion of vibrant things in the Soviet Union signalled the growing self-reflexivity of applied artists and anticipated the extensive debates about design criteria that would unfold throughout the following decades in late socialism.

\section{Up-to-date materialities}

As studies of socialist material culture clearly demonstrate, design in socialist countries was an integral element of socialist modernity. Notably, the landmark exhibition at the Victoria and Albert Museum that manifested the growing interest in socialist design was entitled (quite provocatively) 
'Cold War Modern'.45 The leading historian of post-war Soviet design Susan E. Reid wrote of 'modernization in the Soviet home' and characterised the move towards mass housing and mass consumption, attended by changes in visual culture, as the 'Khrushchev Modern'. ${ }^{46}$ Recent scholarship argues that design in the socialist bloc and in the USSR in particular was a symptom of modernity, a tool of modernisation, a modern phenomenon, as well as a part of international modernism (notwithstanding all the official pronouncements against 'bourgeois modernism').

To be precise, all these terms that extend from the root word 'modern' are highly debated and polysemantic. If we take the understanding of modernism as the critique of, or resistance to, modernity, ${ }^{47}$ then the meaning of design in socialist society appears quite ambiguous. Although Soviet design was generated by modern technology and science and influenced, through competition, by Western consumer culture, it could also offer a critical stance on Soviet modernity itself, particularly this modernity's technocratic aspects. ${ }^{48}$ In the context of Soviet design, modernity can also be considered in the immediate sense of 'contemporaneity' or 'being up-todate', both translated into Russian as sovremennost', literally, 'in tune with the time'. This was the notion that guided designers in their actual work. The abstract idea of modernisation was fuelled by professionals' desire to be cutting-edge. How was this desire translated into concrete strategies of updating consumer goods, interiors and outdoor decorative objects? While designing an aircraft or a vacuum cleaner in the 1960s is clearly a modernising act, what does it mean for a porcelain or textile designer to be up-to-date? Does a glass artist become 'contemporary' only when she or he also starts working with such innovative materials as plastic?

These questions prompt an inquiry into the very possibility of a useful, tangible object expressing the spirit of a present time, especially as defined by the rapid development of science and technology, vibrant consumer culture and fashion. In his attempt to arrive at 'thing theory', Bill Brown suggests that the objects of everyday life are not only constituted by consumer desires and affections, but also by the inevitability of obsolescence. He writes about 'a basic disjunction, a human condition in which things inevitably seem too late - belated, in fact, because we want things to come before ideas, before theory, before the word, whereas they seem to persist in coming after: as the alternative to ideas, the limit to theory, victims of the word'. ${ }^{49}$ According to Brown, the only way for a thing to escape belatedness is to move from everyday life into the realm of art, where it would recapture an affective power. A Surrealist readymade or Claes Oldenburg's Pop-art 'sculptures' are not 'dead commodities', like their obsolescent everyday-life prototypes, but 'living works' that inspire the viewer to reflect upon the meaning of things and their functions. Thus, in Brown's example, Oldenburg's 1999 Typewriter Eraser of shiny chrome possesses the power 'to dramatize the generational divide and to stage (to 
melodramatize, even) the question of obsolescence'. He then generalises: 'Released from the bond of being equipment, sustained outside the irreversibility of technological history, the object becomes something else. ${ }^{50}$

Considering Brown's argument along with Rancière's concept of the aesthetic regime of arts, I suggest that Soviet designers aspired to release the object from the doom of obsolescence by transcending the 'basic disjunction' between ideas and things and between art and everyday life. In this attempt, they relied on the theory of productivist art, which notably developed concurrently with Surrealism. ${ }^{51}$ Boris Arvatov stated the following in his 1925 article 'Everyday Life and the Culture of the Thing' (Byt i kul'tura veshchi): 'The construction of proletarian culture, that is, of a culture consciously organised by the working class, requires the elimination of that rupture between things and people that characterized bourgeois society. ${ }^{52}$ Arvatov explained that as soon as class barriers fall, so do the divisions between labour and daily life and between production and consumption. In a bourgeois society, things are passive and static merely ready-made objects to be rearranged (Arvatov's argument, I would suggest, is aptly illustrated by Duchamp's readymades). In the upcoming proletarian society, on the contrary, the thing becomes dynamic and active: "The mechanism of a thing, the connection between the elements of a thing and its purpose, were now transparent, compelling people practically, and thus also psychologically, to reckon with them, and only with them.' 53 Such 'affective' objects ${ }^{54}$ seem to be immune from obsolescence and, therefore, always up-to-date. Arvatov's 'dynamised' thing offers the possibility of continuous updating, in tune and in connection with the world of technology. Was this idea implemented, at least partially, in industrialised Soviet society, as it faced competition with Western consumerism in the 1950s and 1960s? This question will be explored throughout the following chapters. As a starting point, I consider the exercise in updating material culture conducted at the turn of the 1960s in relation to the construction of the Moscow Pioneer Palace. This case is significant as a landmark in Soviet modernist architecture and aesthetics, oriented at fostering the post-Stalin generation as the future inhabitants of communist society. Accordingly, the palace was built as a model for a future society with a harmonious material culture. Before my analysis of this vision, a brief explanation of the Pioneer Palaces (of which there were many) as an institution is in order.

Pioneer Palaces (or Pioneer Houses) were Soviet institutions, subordinate to the Ministry of Enlightenment in each Soviet republic and aimed at providing a well-rounded creative education for children and adolescents. Their programmes, which included a diverse set of activities from singing to aircraft modelling and from theatre to sports, were established and guided by the All-Union Lenin Communist Youth League or Komsomol. Pioneer Palaces were the headquarters of the Pioneer organisation that 
emerged under the auspices of Komsomol in 1922 to prepare children from the ages of 10 to 15 to become proper Soviet citizens. The first Pioneer House opened in Moscow in 1922 and they spread throughout the USSR in the 1930s; by 1939 there were 852 in Soviet Russia alone. ${ }^{55}$ Early Pioneer Houses were located in former aristocratic mansions, and those built in the 1930s often imitated classical models.

In 1958 the Komsomol Central Committee began to plan a new Pioneer Palace, which would be built from modern materials and be radically different from previous palaces. The chosen location, the Lenin Hills in the south-west of Moscow ('Sparrow Hills' before 1935), had traditionally been a popular leisure resort for Muscovites. Under Stalin, it gained importance as the location of the grandiose Moscow State University (MGU), one of the 'Seven Sisters' skyscrapers built between the late 1940s and the early 1950s as landmarks along with the never-realised Palace of Soviets. In the second half of the 1950s, Moscow's south-west region became a site of experiments in innovative urban planning and architecture, from the second project for the Palace of Soviets (also eventually abandoned) to the residential bloc of five-storey prefabricated buildings, the 'New Cheremushki'. ${ }^{56}$ Accordingly, the Lenin Hills needed a new post-Stalin and 'post-excess' landmark, an architectural response to the MGU. In 1958 the Komsomol Central Committee and Moscow Party Committee announced a competition for the palace that would reflect the newest construction techniques as well as the Pioneer Palaces' task of building a future communist society. Unlike other Pioneer Palaces, it was not supposed to be one building but a whole complex of buildings, for which a 54-hectare plot in a park was assigned. ${ }^{57}$

The winners of the competition were a team of young architects from the construction institute Mosproekt: Viktor Egerev, Vladimir Kubasov, Feliks Novikov and their leader Igor' Pokrovskii. In resonance with contemporary tendencies in Western architecture and in contrast to the custom of the Stalin era, they suggested placing the building well within the plot rather than next to a street. ${ }^{58}$ Their plan was for the palace complex to have one main, two-storey building with four perpendicularly attached wings. The main building was to be connected by a gallery to a concert hall. The main building and the concert hall would comprise an 'L' shape abutting the parade ground, where Pioneer ceremonies would take place. The plan also included several semi-enclosed outdoor spaces for various activities, which opened into the park where there would be recreational structures such as pavilions and artificial lakes. All the buildings were to be constructed using industrial methods from standard blocks of reinforced concrete. ${ }^{59}$

The project was further expanded with the help of the architects Boris Palui and Mikhail Khazhakian. It was envisaged as a crucial component of the new centrifugal city plan and an embodiment of the Khrushchevist 
decentralisation of power, socialist democracy, and new optimism about scientific and technological progress. Egerev and his team employed the principles of free planning and functionalism, ${ }^{60}$ characteristic of the architectural modernism of the 1920s-1930s, which now expressed the new Soviet ideals of the post-Stalin era. Thus, elements that were commonplace in Western architecture were reinterpreted on Soviet soil as innovative forces for the negation of Stalinist art deco and neoclassicism.

The palace's interiors also had to speak to the new direction of Soviet architecture. For this purpose, the construction team enlisted recent industrial art graduates from the Moscow Higher School of Art and Industry (MVKhPU). This decision was not accidental: the palace was designed by young architects (all, except for Khazhakian, younger than 40) for a young audience, the next generation of the Soviet people. Accordingly, the palace's interiors and environs would also be best designed by young people, who had started their design education in September 1954, only just before the famous anti-excess resolution, and who had generally not been exposed to Stalin-era aesthetic principles such as obligatory figurativeness, focus on subject matter and lush decoration. In addition, MVKhPU benefited from being involved in the palace's design because this suited the all-Union school reform, conducted by the Soviet government since 1958. ${ }^{61}$ A part of this reform was the resolution 'On the forms and terms of education in higher institutions and the production internship of students', issued by the USSR Soviet of Ministers in August 1959.62 In particular, it obliged full-time students of higher art schools to work as employees or paid interns in industrial enterprises for one year. The topics for graduation projects for the academic year 1959-60, given out by MVKhPU in September right after the issuing of the resolution, were all related to practical subjects - mass housing, public buildings, public transport and factory equipment. The projects for the palace's interior perfectly suited the Party-led campaign to update the architectural, social and cultural landscape of the Soviet capital city.

During the academic year, over thirty-three students were expected to design furniture, lamps, lattice screens, fountains, monument plaques, decorative sculptures and other types of decorative and utilitarian furnishings. ${ }^{63}$ The students were granted access to workshops and had the technical assistance of the team of architects who designed the palace. In June 1960 the students presented their drawings and models to the State Examination Committee. The committee included the palace's architects Egerev, Kubasov and Khazhakian, as well as engineers Nikolai Maikov and Iakov Kerzon.

Several designs for the palace stemmed from the departments of metalworking and carpentry at the Faculty of Industrial Art, headed by architect and designer Aleksandr Korotkevich. ${ }^{64}$ These two departments exemplified the continuity between the 1920s Russian avant-garde and 
post-war Soviet design. They both incorporated woodworking and metalworking traditions from Vkhutemas and the teaching of such prominent instructors as Vladimir Tatlin, Aleksandr Rodchenko, El Lissitzky and Anton Lavinskii, who decisively broke with methods of traditional applied art and introduced advanced propaedeutic courses and technical disciplines. In 1926 the two departments were united into the department of carpentry and metalworking (known as dermetfak), which became the cradle of Soviet proto-design by training 'the first detachment of qualified designers', as Selim Khan-Magomedov phrases it. ${ }^{65}$ In the late 1950s two of these pre-war graduates, Zakhar Bykov and Nikolai Sobolev (noted as being among Rodchenko's best students by Varvara Stepanova in 1923), 66 headed the MVKhPU departments of metalworking and carpentry, respectively. Bykov was the school's rector. Another dermetfak graduate, Boris Sokolov, taught in the carpentry department and supervised several graduation projects for the Pioneer Palace. What could their own students, intellectual 'grandchildren' of Rodchenko and other constructivists, offer for the crucial construction project of the Khrushchev era?

Furniture design was a particularly important point of continuity between Vkhutemas and MVKhPU. In the 1920s the ideal of asceticism in everyday life was generated both by economic necessity and by collectivist spirit, and projects for collapsible furniture were of equal interest for architects, designers and workers who inhabited rooms appropriated from the bourgeoisie and the newly built house-communes. Boris Arvatov celebrated collapsible furniture as an example of a new thing, 'functional and active, connected like a co-worker with human practice'. ${ }^{67}$ In accordance with the productivist image of socialist objects, students of dermetfak at Vkhutemas designed various types of collapsible furniture, mostly made of wood, but in some cases also with steel tubes. After graduating in the late 1920s, some of these 'pioneers of Soviet design' ${ }^{68}$ entered factories and influenced, though on quite a limited scale, Soviet furniture production. ${ }^{69}$

After the dominance of traditional furniture from the 1930s to the early 1950s, collapsible furniture again found state and Party support as a tool for modernising material culture. This time though, unlike in the 1920s, the industry had the capacity to produce such furniture on a mass scale. Thus, Arvatov's 'co-workers' could now enter every Soviet home. Modernist public buildings such as the Pioneer Palace were supposed to display the best prototypes of mass-produced furniture. The three-decadelong interruption in furniture design education, however, meant that Soviet metal furniture was still, in the opinion of Khazhakian in 1960, 'a lame-duck industry' (samyi otstaiushchii front). ${ }^{70}$ While assigning furniture designs to students, the palace's architects also conducted research on the latest models of Finnish and Swedish furniture and as a result ordered 40 per cent of all of the palace's furniture from Finland. They later regretted their decision when they saw the student projects, which far surpassed 
their expectations. The architects decided that the student designs were of a high enough quality to equip the entire palace and were no worse than the Finnish furniture. The Soviet Union's lagging behind the West looked as if it was coming to end, at least in the field of furniture design.

In June 1960 both the carpentry and metalworking departments of MVKhPU presented metal furniture designs. Metalwork students combined metal frames with plastic and carpentry students combined them mostly with wood. ${ }^{71}$ As a type of progressive furniture, invented and popularised by the Bauhaus student Marcel Breuer, tubular steel furniture appeared to be the most suitable for the new palace. This decision reflected a broader campaign for the updating of furniture production, begun by the Soviet government after 1958 in connection with the construction of mass housing and as a response to high demand. ${ }^{72}$ The use of new technologies and materials, such as plastics and rubber foam, was promising as a way of overcoming the outdatedness of furniture production. This naturally necessitated new forms for the furniture itself. As architect N. Borushko expressed it in the summer of 1960, 'the established types of sideboards, cupboards, beds, etc., cease to be attractive not just because their size does not fit in contemporary flats, but also because outdated forms do not correspond to new aesthetic views' ${ }^{73}$ As such, the Pioneer Palace's furniture was the most convenient space to demonstrate cutting-edge Soviet designs, suitable for the more modern needs of the next generation.

When evaluating students' furniture projects, the term 'lightness' was often used by the examination committee. Outdoor furniture for the shore of an artificial lake in the palace's park was presented by its designer Igor Akimov as 'convenient, light and beautiful, and also easily collapsible, so it would last longer and be conveniently stored in winter' ${ }^{74}$ The furnishings for the waiting rooms, designed by Elena Bondarenko, would include convenient wooden chairs 'of a very light type'. ${ }^{75}$ Valentin Konovalov's equipment for the concert hall was praised for the use of 'new progressive materials: thin-walled metal tubes in place of massive legs for chairs and foam rubber for seats instead of springs' ${ }^{7}{ }^{76}$ For the kitchen of the palace's 'housekeeping school', the student E. Fomina designed functional and hygienic furniture arranged along the walls. Her reviewers found the design simple and convenient: the plastic coatings of work surfaces could be easily cleaned, while the central table had narrow metal legs that would appear light and evoke a sense of spaciousness. ${ }^{77}$ Similarly, for the palace's park, Nodari Gogoberidze designed benches, chairs, tables and chaise-longues that were 'firm, light and easily transportable', easy to collapse, but also brightly coloured and reasonably cheap in terms of production costs. ${ }^{78}$

I suggest that 'lightness' here acted as a signifier of cutting-edge design, or what the philosopher Charles Peirce calls a 'qualisign'. ${ }^{79}$ In her study of the material culture of socialist Hungary, anthropologist Krisztina 
Fehérváry uses the concept of a qualisign to explore, within the framework of Peircean semiotics, the influence of materialities on the process of signification. As she explains, qualisigns are qualities that 'can produce affective responses that may or may not come to constitute a recognizable aesthetic regime'. Textures, colours and properties, found in multiple objects, substances and bodies, have the potential to become qualisigns: 'The qualia of grey in a rug, for example, is shared by a slab of concrete, a dawn fog, and pebbles on the lakeshore; this grey usually mingles with other material properties such as texture or fragility. ${ }^{80}$ According to Fehérváry, the presence of qualisigns allows diverse realms to be combined into a coherent style. Relying on this argument, one can suggest that post-Stalin 'contemporary style' was built upon the physical qualities of materials rather than a lexicon of figurative elements.

Lightness, therefore, acted as a crucial evaluation criterion and defined both the praise and criticism of post-Stalin Soviet designs. Two examples are particularly illustrative. First, the carpentry student M. Vlasov-Klimov was challenged with designing the palace's dining hall, with space for 176 people and a passageway for a worker with a food-cart. ${ }^{81}$ The task was further complicated by the unusual ellipsoid shape of the room, with a sail-shaped ceiling supported by a solid pillar in the centre, and a large glass wall that looked out on a stadium and pond. Vlasov-Klimov handled the task by designing small square tables, easily adjustable to the curve of the wall and to the position of the pillar. The tables were accompanied by light chairs of innovative construction: the seat and back were a single piece of bent nine-layer plywood, and the legs were two steel tubes that intersected at one point and were fixed to the seat. The tables would have two tops, the lower serving as a shelf for children's possessions. The front surface of the chairs and the tops of the tables would be PVC and coated in a nitrocellulose lacquer. Vlasov-Klimov also presented models for a sharp-cornered collection table for dirty dishes and a complex buffet table, probably inspired by the late 1920s projects for kitchen units and transformable furniture. The buffet would include a table with two glass display cases, a cold-air unit and several shelves of adjustable height.

Nikolai Sobolev, a Vkhutemas graduate and the head of the carpentry department, found the table design uneconomical: "Why such effort just to support the tables? I calculated that you used [altogether] forty metres of excessive tubes, while we always use metal sparingly. ${ }^{82}$ Vlasov-Klimov defended his choice: the legs were fixed to the middle of a table top rather than its sides so that they would not disturb the legs of the sitters. Such a construction, though ergonomic, is not sufficiently stable and requires an additional fixing element - hence the use of extra tubes. Several committee members disapproved of the shape of the table for dirty dishes. Zakhar Bykov, another Vkhutemas graduate and head of the metalworking department, called it 'accidental and unwarranted' and, contrary to what 
Vlasov-Klimov claimed, difficult to keep clean. In addition, Bykov and the engineer Nikolai Maikov criticised the pointed angles of the table top as 'somewhat disturbing' and suggested that rounded angles would be safer for children approaching the table with used dishes. Vlasov-Klimov explained that the sharp square form of the table top was determined by the parameters of the interior.

The quality of lightness, implied by tubular steel furniture, also appeared questionable: one committee member doubted that children would be able to move the chairs. Vlasov-Klimov again reassured his critics that the chairs were 'very light', and that their rubber 'feet' also made them more stable. These arguments revealed the contradictions between different principles of modernist design, embraced by Soviet architects and applied artists by 1960: economy, functionalism, ergonomics and ease of maintenance. While trying to follow some of these principles, VlasovKlimov unwittingly violated others. Square tables might be elegant but could also be potentially dangerous for their users. Formal considerations overshadowed ergonomic requirements. In the case of the tables' legs, ergonomic considerations meant the overuse of production materials. These shortcomings were easily explicable in terms of the designer being a student who lacked experience. Yet they represent the contradictory legacy of Vkhutemas design that influenced Soviet design education in the late 1950s but was mostly untraceable in an everyday environment. The students needed to reconcile the requirements of aesthetic novelty, user-friendliness and economic efficiency.

The second example of lightness was the case of V. Goriunova, another student in the carpentry department, who designed furniture for a very spacious playroom for schoolchildren between the ages of 7 and 9 (oktiabriata), located in the main building of the palace in the winter garden. ${ }^{83}$ Her work was influenced by the specific nature of the room's walls: two walls were replaced by sliding glass doors, the third wall was made of wooden blocks and the fourth wall totally from glass; with opening side doors, the hall would be united with the main enfilade of the palace. In accordance with contemporary ideas on communist upbringing and educational space, ${ }^{84}$ Goriunova was instructed to create a dynamic and interactive interior. The existing Soviet educational institutions did not provide her with proper models for emulation: 'There was nothing to look at.' Rejecting interiors that were familiar to her, Goriunova attempted to create a completely new arrangement of furniture, toys and wall decorations, where everything could be a tool for entertainment and education. She explained, 'I aimed to create conditions for the children to feel free; to create a specific children's world. Therefore, I proceeded from the principle of simple forms, accessible and amusing for children.' She designed collapsible furniture that could be easily folded when the hall was in use and stored in the general enfilade. Using wooden pieces and foam-rubber 
cushions, children could compose their own furniture, such as a table or couch. The toys were also designed to be collapsible and connectable. Architect Sergei Nikulin approvingly noted that both furniture and toys would stimulate children's creativity and interest in collective games, which would be 'correct in terms of the methodology of upbringing'. The sliding partition walls would be decorated with appliqué landscape compositions that would correlate thematically with the actual landscape visible through the glass wall. Presuming that an opaque wall would look boring, Goriunova decorated it with geometric patterns in mild colours. In all the decorations, she claimed to have relied 'on children's drawing and children's taste'. To make the children's play more comfortable she suggested covering the floor with a grass-like mat. Despite criticism that some toys' details could not be easily repaired if broken, her project generally met the expectations of the palace's architects.

Goriunova's approach to the playroom echoed the idea of playfulness that was prominent among post-war architects and designers in Europe and the US. As Sarah W. Goldhagen explains, an important component of this was the idea of homo ludens, human being at play, inspired by Johan Huizinga's 1938 book of the same name. Play, understood as the source of spontaneous self-expression and resistance to socio-political pressure, required proper architectural spaces. Accordingly, play often served as a reference point for architects, such as Alison and Peter Smithson and Cedric Price in Britain, Jaap Bakema and Aldo Van Eyck in the Netherlands and the members of the Situationist International in France, especially in the late 1950s. ${ }^{85}$ Although Soviet architects and applied artists were concerned with facilitating collective leisure activities at that time, unrestricted playfulness was not considered to be a crucial part of human life. Childhood, however, was a prominent exception. The objects Goriunova designed were presented not as 'co-workers', like those designed by Rodchenko, but as toys or playmates. Goriunova's playroom, as well as the whole Pioneer Palace project, was envisioned as a segregated space of freedom within an otherwise regimented socialist society.

All the projects for the palace from the metalworking and carpentry departments - sixteen altogether - were expected to be implemented by the end of 1960. Khazhakian called for the finding of 'organising forms' for realising the projects in situ. 'It could be said that we are witnessing the birth of a great mastery', he mused. ${ }^{86}$ Architect Georgii Zakharov, the pro-rector of MVKhPU, stated that the defining of these 'organising forms' should be the responsibility of the palace team and Komsomol as much as of the school. ${ }^{87}$ However, cooperation between the palace's architects and the MVKhPU administration remained only at the level of good intentions. In April 1962, three months before the opening of the Pioneer Palace, the administration board of the Moscow Organisation of the USSR Union of Architects met with the MVKhPU representatives to discuss the students' 
graduation projects and the prospects for their implementation into industry. At this meeting, rector Bykov complained that architects rarely turned to MVKhPU for help, and even if they did, the student works that came out of this were often neglected. He cited the Pioneer Palace as a vivid example: 'Unfortunately, none of the student projects has been realised, even though they all have been approved and the students strongly wished to implement them in situ. ${ }^{\prime 8}$ The available sources do not show that palace architects ever replied to this charge.

The palace was opened on 1 June 1962 on the International Day for the Protection of Children, with a grand ceremony. The book authored by the palace's architects, as well as archival sources, reveal that some of the MVKhPU projects were in fact implemented in modified forms without the involvement of the students or acknowledgement of their work. These sources, however, do not indicate the reason behind this decision of the architects (it was not a legal problem since student works were not protected by Soviet copyright law) ${ }^{89}$ It is most likely that, while the students' ideas were indeed appreciated as relevant and innovative, the inclusion of students in the palace team long-term would have simply been too arduous organisationally and would have slowed down construction.

Vlasov-Klimov's suggestion of having square tables with thin metal legs was implemented in the end. As in his original design, the table tops were coated with white plastic and the chairs with red. ${ }^{90}$ His idea of having chairs made from a single piece of bent plywood was rejected in favour of a more conventional chair with a metal frame. However, his chair design did appear in the buffet of the Pioneer Theatre, but it is likely that these were actually modelled on contemporary Nordic furniture rather than Vlasov-Klimov's design, given that some of the palace's furniture was produced at Finnish factories. ${ }^{91}$ Indeed, Vlasov-Klimov himself could have very well imitated these same Finnish models. The rest of the furniture in the palace (Egerev does not specify the percentage) was designed by the Central Moscow Project and Construction Bureau of Moscow sovnarkhoz (TsMPKB), probably including the café's chairs, which clearly lacked the elegant simplicity of Finnish furniture. These chairs were obviously solid enough to withstand wear and tear from their young and hungry occupants, just as Vlasov-Klimov's chairs were supposed to do, but en masse they formed a rather chaotic assembly, a forest of metal legs, somewhat in discord with both the transparency of the café's wall and the sturdiness of its reinforced concrete support. Their slightly clumsy form would soon become ubiquitous throughout the USSR until the country's collapse, and the chairs remained in many public buildings, such as schools and cafeterias, well into the $1990 \mathrm{~s}$ - obsolete, material signifiers of a past era.

V. Goriunova's project for the oktiabriata playroom was also partially modified. Reporting on the palace's opening, the official newspaper of the Komsomol paid special attention to this room: 


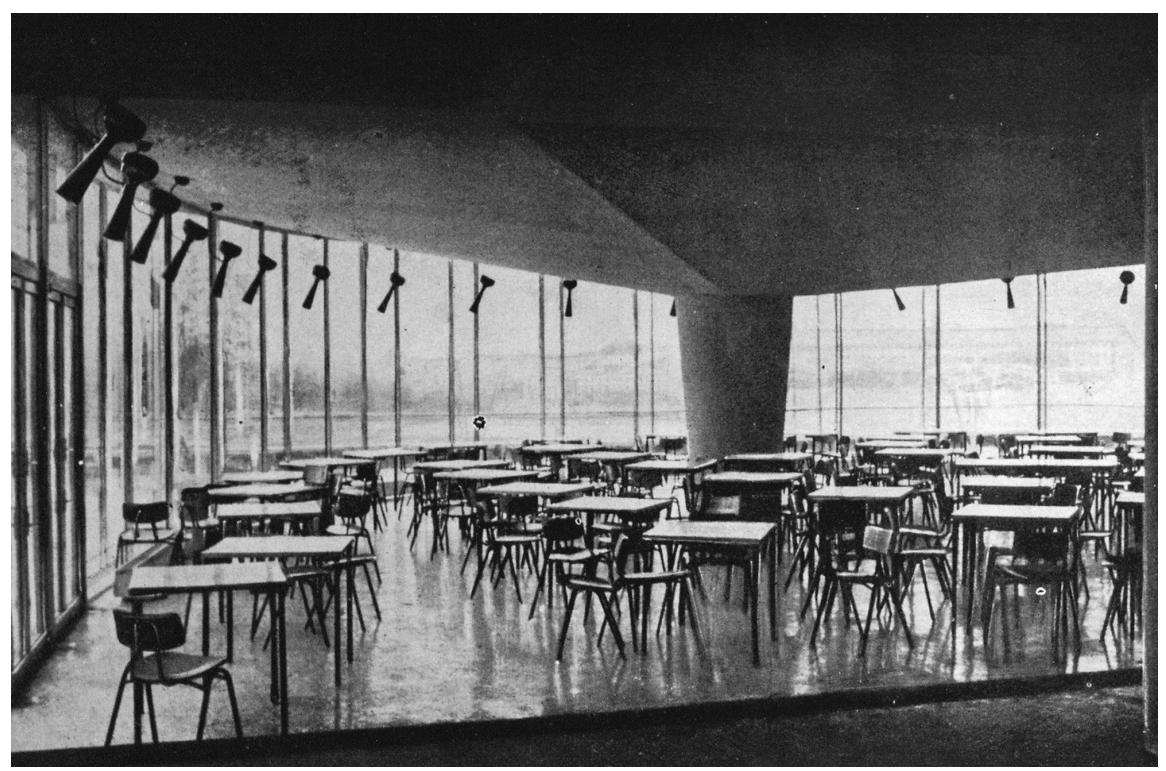

All rights reserved and permission to use the figure must be obtained from the copyright holder.

1.1 Pioneer café interior in the Pioneer Palace on the Lenin Hills, 1961.

To the right [from the winter garden], behind the wall is a green lawn. This is the oktiabriata room. The floor is covered here by a thin carpet of soft plastics, and all the toys are on the floor. They are selected in such a way that one cannot play with them alone - only with peers. ${ }^{92}$

In his book, Egerev specified that the carpet was made from nylon, and the toys were 'cars and cranes, construction equipment, rockets and ships, dolls and bricks - everything that can give joy to a child' ${ }^{93}$ The emphasis on joy, rather than prohibition and punishment, echoed Goriunova's emphasis on entertainment and freedom of movement in her project. Indeed, two of her suggestions - the green, grass-like carpet and the dynamic toys - were incorporated by the architects in the actual room. However, instead of the sectional furniture in the original project, TsMPKB designed low tables with multagonal shapes. Although irregular and amusing, these tables were static props for children's games rather than transformable objects/ playmates. The decoration of the glass partitions, another of Goriunova's suggestions, was also neglected in favour of transparency and, implicitly, easier control over the playing children. As a result, the actual playroom environment turned out to be more restrictive of children's freedom than Goriunova's design had intended.

While the story of the students' painstaking work on designing the interior of the Pioneer Palace has been mostly forgotten, the building itself, on the contrary, has since become one of the main icons of Khrushchev-era Soviet modernism. ${ }^{94}$ Enthusiastic reviewers praised the palace complex 


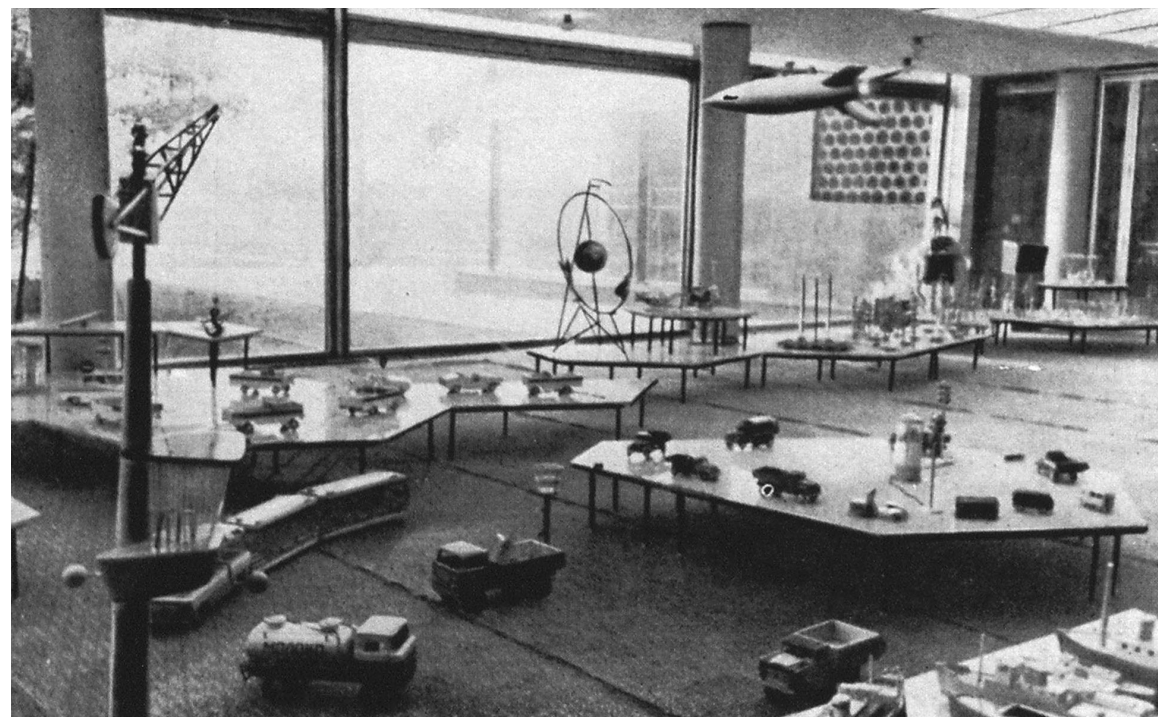

All rights reserved and permission to use the figure must be obtained from the copyright holder.

1.2 Playroom for young children in the Pioneer Palace on the Lenin Hills, 1961.

with its numerous courtyards and artificial lake as a 'country of romantics'. Professional critics believed it to be a breakthrough, or, as Lebedev phrased it, 'a leap forward in the process of architectural development'. ${ }^{95}$ In the eyes of its contemporaries, the Pioneer Palace came to signify the Soviet Union's catching-up with modernity and an overcoming of its backwardness and its Stalinist past. The palace's interior spaces, too, were perceived in that light. But behind this joyous image were clashing visions of what constituted modernity and functionality, of what was feasible and financially viable - visions held by different generations of designers and architects over what the future communist generation should be.

\section{Excess and taste}

A 1964 film by Vasilii Shukshin called There is Such a Lad (Zhivet takoi paren') has a memorable scene. ${ }^{96}$ The main protagonist, the young truck driver Pashka (Pavel) Kolokolnikov, gives a lift to an educated woman from the city on a remote Siberian road. Pashka complains that country life is boring, and the woman answers that it is the villagers' own fault, because they fail to make their lives 'truly beautiful'. She additionally argues that the beauty is in the detail: 'I have just been in the home of one young [female] collective farmer. She's got all kinds of stuff! Pillows, bedside tables, stupid elephant figurines ... What do you think is it for? For "happiness". You're a young man - don't you understand?' On Pashka's awkward attempt to defend domestic cosiness, she responds didactically: 
Look, it is philistinism! Elementary philistinism. Incredible! Is it so difficult to replace all this with two or three reproductions of contemporary artworks, to have an ottoman instead of a merchant-style bed, to buy a floor lamp? By the way, lighting means a lot. To place a contemporary beautiful vase on the table. Is it really so hard? And such furnishings will be no more expensive Ithan the familiar ones]!

This passionate speech resonated with numerous articles on good taste that appeared in the Soviet press prior to the early 1960s. Obviously, the educated passenger is familiar with them. She has absorbed the expert discourse on good taste, and now acts as an agent of modernisation in the countryside. Her speech indeed affects the driver, an open-hearted country lad. The next shot captures Pashka's fantasy: a room arranged in a minimalist fashion, with modest furniture, window curtains with geometric patterns and a few reproductions on the walls, one of them even featuring abstract painting. This is a recognisable picture which one could have seen mirrored in Dekorativnoe Iskusstvo SSSR, Tekhnicheskaia Estetika or even the popular magazine Ogoniek. A young woman in the latest dress, with a bubble haircut, welcomes Pashka in 'French' to his fantasy home. He appears as a caricature of himself, wearing a suit and a top hat, pretentiously imitating French speech.

The scene ironically reveals both the ubiquity of Soviet taste advice and its insensitivity to specific contexts, which led to superficiality and absurdity. However, did Soviet design professionals really believe, like Pashka, that the beauty of daily life is achieved by simply throwing out knick-knacks and getting a floor lamp? What was behind the post-Stalin dictatorship of taste?

Taste is a complex concept, laden with social, economic and political factors. For more than a century, taste has been discussed extensively by sociologists (and from the 1980s also by anthropologists) as not only a matter of aesthetics but also a powerful marker of social stratification and a tool for building symbolic hierarchies. ${ }^{97}$ In his celebrated book, Pierre Bourdieu presented taste as a key component of habitus - the generative principle for social practices and simultaneously the system of their classification. He argued:

Taste, the propensity and capacity to appropriate (materially or symbolically) a given class of classified, classifying objects or practices, is the generative formula of life-style, a unitary set of distinctive preferences which express the same expressive intention in the specific logic of each of the symbolic subspaces, furniture, clothing, language, or body texts. ${ }^{98}$

In particular, Bourdieu emphasised that the tastes of dominant classes are largely built on restraint: 'It is well known that all dominant aesthetics set a high value on the virtues of sobriety, simplicity, economy of means, which are as much opposed to first-degree poverty and simplicity as to 
the pomposity or affectation of the "half-educated". ${ }^{99}$ This dominant aesthetics is appropriated not only by the upper middle class, the possessors of economic capital, but also by middle-class intellectuals, for example secondary and higher education teachers, endowed with strong cultural capital but often with fewer economic resources.

Even though Bourdieu's theory has been criticised as reductionist and applicable only to France, his understanding of the negation of the 'vulgar' as the act of social distinction accurately characterises the modernist stance against ornamentation. This modernist critique not only targets the pitfalls of mass production but also demonises the "uneducated public ... with too much money and no time, or with no money and no time', as Nikolaus Pevsner phrased it in his famous history of modern architecture. ${ }^{100}$ Taste, therefore, is never socially and politically innocent it is intimately linked with social hierarchies and can be instrumentalised by intellectuals as a marker of their symbolic superiority over the 'uneducated public', or as a tool for radical criticism of mass culture stemming from capitalist economic conditions, as was done by Marxist thinkers from Theodor Adorno to Guy Debord. ${ }^{101}$

Under state socialism, such a class distinction as described by Bourdieu would be unthinkable. Several scholars have recently stressed a holistic understanding of culture, officially promoted in the Soviet Union from its beginning until perestroika. Instead of 'high' and 'low' or 'mass' and 'elite' cultures and diverse lifestyles, Soviet officials and professionals spoke of a universally popular and enlightening culture in which ballet, classic literature, film comedies and folk art were harmonically combined - 'an anti-masscult culture for the masses', in the apt words of Kristin Roth-Ey. ${ }^{102}$ This implied a single universal taste. Yet the notion of a homogeneous culture was an ideological construct in Soviet society, which, as Stephen Lovell rightly notes, concealed various tensions and inequalities that never disappeared under socialism. ${ }^{103}$ I suggest that taste, as it was configured in Soviet public and professional discourses, can be perceived as an unwitting acknowledgement and even barometer of these tensions.

In the 1920s taste was mostly portrayed in a negative way, as a hindrance to the rational reorganisation of social life in a post-revolutionary society. While in capitalist, French society, as Bourdieu suggests, tastes are justified through the refusal of other tastes and thus 'tastes are perhaps first and foremost distastes', ${ }^{104}$ in Soviet society taste was often defined as an attribute of the defeated aristocracy and petite bourgeoisie. Accordingly, with the reappearance of the latter as Nepmen in the time of the New Economic Policy, taste became a characteristic of the class opponent for leftist intellectuals, especially the artists associated with Proletkult (an artistic organisation under the Commissariat of Enlightenment) and the journal $L E F$. In the new proletarian Soviet culture, taste had to be replaced 
by a technical and utilitarian necessity; this stance was vividly expressed in the famous composition-construction debate at the Institute of Artistic Culture in January-March 1921. Osip Brik declared enthusiastically in 1923 that the constructivist artist Rodchenko was 'revolutionising taste', ${ }^{105}$ while Arvatov portrayed taste in 1925 as an inherently bourgeois idea, a symptom of the alienation of consumption from production that would eventually be overcome in a proletarian society. In the broader sociopolitical context, taste appeared as a pejorative term in the state-supported campaign for the reorganisation of everyday life (byt) when the NEP was being curtailed and during the first Five-Year Plan. One of the strongest voices of this campaign, the newspaper Komsomol'skaia Pravda (the official print organ of the Communist Youth League), repeatedly urged its readers in 1928 to break 'the dictatorship of the workshop of faience figurines' and 'summon bric-a-brac to public trial'. ${ }^{106}$ Bad taste in home furnishing came to signify an alien class ideology.

As several recent studies have demonstrated, the 1930s, especially following the abolition of rationing in 1935, was a time when a specific Soviet consumer culture was formed that reflected the new social hierarchies of an allegedly classless society. ${ }^{107}$ This new social order was disrupted by the dramatic experience of the Second World War, whose devastating impact was felt long after the official proclamation of victory. War trauma and exhaustion, as well as Soviet soldiers' encounters with Central European countries during the offensive of 1944-45, prompted a desire for better living standards and even modest luxuries as justly earned by sacrifice. ${ }^{108}$ Therefore, the painful process of post-war recovery and reconstruction was accompanied by the flourishing of the black market. ${ }^{109}$ In these circumstances, taste emerged as both a resonance and instrument of social change: people often showed a penchant for material possessions - which became, as Vera Dunham famously argued, the prerogative and reward of the newly formed middle class. ${ }^{110}$

The social order was shaken again by the death of Stalin and Khrushchev's denunciation of his 'personality cult' and abuses of power at the XXth Party Congress in 1956. Khrushchev's reforms, most prominently the full-scale expansion of mass housing and the establishment of cultural exchange with the West, intensified industrialisation, scientific and technical progress and the dramatic growth of cities ${ }^{111}$ and opened the door to the diversification of taste. Simultaneously, the campaign against architectural 'excess' brought strictures on domestic comfort and decoration, both in everyday life and in artistic production. In the case of everyday life, moving to a one-family, prefabricated flat from a communal one meant not only an advance in living standards but also the rejection of old beloved possessions, such as massive ornate furniture. Decorative artists could now use mass housing as an argument for their important status as creators of furnishings and arbiters of taste, but they also had to solve the 
methodological puzzle of translating new principles of architecture into their profession. ${ }^{112}$

Since the aesthetic turn occurred largely as a result of architectural reform, the materials and designs of mass housing greatly influenced the idea of good socialist taste. I argue that honesty was a core value of this new taste. The advocates for the modernisation of Soviet architecture emphasised honesty as a positive value behind unadorned façades and industrial building methods. Applied artists, too, tended to view honesty as one of the main virtues that they should pursue in their work. While they did not always use the word 'honesty' (pravdivost' or chestnuts'), the theme of honesty as opposed to dishonesty (usually connected to pretension) ran through their professional discourse in the late 1950s and the early 1960s. This theme was expressed with different words, such as 'clarity', "harmony' or the 'accordance of form to material and function'. I suggest that, by appealing to honesty, design professionals were looking for a symbolic order that would unite art, industry and consumption in a way appropriate for a Soviet society overcoming the traumas of war and late Stalin-era oppression. At the decisive time of defining the future trajectory of decorative art, honesty emerged as the core of the socialist object, the basis for its symbolic meaning, utility and social impact. The notion of an 'honest' object can also be viewed in the context of the intelligentsia's hunger for 'objective truth' and sincerity after Stalin's death and especially after the XXth Party Congress. ${ }^{113}$

Criticism of excessive and pretentious ornamentation appeared in the Soviet press even before the official attack on architectural excess. In September 1954, the journal Sovetskaia Torgovlia (Soviet Trade) published an article by the art historian Aleksandr Saltykov, in which he explained to workers that a good commodity is 'first of all convenient, solid and durable'. According to Saltykov, commodities that failed to meet this criterion had to be rejected as kitsch (khaltura) that 'distorts people's ideas of art and spoils the taste of broad masses', and should be officially withdrawn from trade by the USSR Central Council of Producers' Cooperatives. ${ }^{114}$ In a 1955 article, already in tune with the changing policy of architecture and building, Saltykov promoted the idea of honesty, which was addressed to applied artists and the managers of artistic organisations. He argued that 'artistry in decorative-applied art means first of all that the object clearly manifests its function by its appearance, being itself in form and material, and not imitating anything else'. ${ }^{115}$ This article was an attempt to justify applied artists' preference of form over decoration, which should not be mistaken for 'bourgeois formalism': form deserved attention as long as it was 'honest'. Disregarding plain forms is an unfortunate mistake, Saltykov claimed, because '[t]he object itself must also be beautiful, its proportions, silhouette, and contours must be perfect, vibrant, emotionally saturated; its parts must constitute a well-rounded harmonic whole, simply 
and clearly expressing its practical destination and fully corresponding to its material'. 116

This article by Saltykov presented the first publicly available portrayal of the image of a socialist object. A socialist object should be well proportioned and clear, should not try to seduce its user but honestly declare the way that it was manufactured and the way it should be used. Saltykov's argument can be interpreted as the reinvigoration of the 1920s productivists' focus on construction, the necessary and sufficient basis of an artwork, rather than composition, an arbitrary and subjective arrangement of superfluous elements. ${ }^{117}$ Design professionals in the 1950 s demonstrated a similar strategy to that of the productivists: the belief in the honesty of the material as opposed to the changing 'Party line' and ideological pronouncements, the striving beyond ornamentalism towards the essence of things, towards the embodiment of the labour of an artist and a factory worker (who were, contrary to the productivist ideal, usually different people).

However, professional discussions and published texts of the 1950s betray a hesitancy to completely deny the 'mystery' of artistic creativity and, indeed, the importance of aesthetic appeal. To use the constructivist vocabulary again, the aesthetic turn was to a great extent organised around the fluctuation between 'composition' and 'construction'. For example, the glass artist and architect Boris Smirnov, at the theoretical conference at the Mukhina School in January 1954, argued that too much fixation upon functionalism leads to economic inefficiency, because ordinary Soviet people possess an inherent 'artistic sense' and expect a commodity to be first of all beautiful and only then convenient and durable. ${ }^{118}$ Furthermore, according to Smirnov, the prevalence of constructive and 'functional-physiological' aspects was a feature of capitalist commodities, such as 'ultra-fashionable furniture'. One can read this as the reverse of the constructivist credo: exposed functionalism ('construction') as the source of commodity fetishism, and beauty ('composition') as the distinctive trait of a socialist object. However, design professionals, including Smirnov and Saltykov, undertook a more sophisticated attempt to draw the line between socialist honesty and dishonesty across the realms of function/construction and ornamental/aesthetic appeal. In search of appropriate criteria, they turned to folk art, which had been officially praised as an expression of truly popular creativity since the mid-1930s. In doing so, design professionals did not simply emulate the official rhetoric, but also followed the tradition of the professional study, preservation and promotion of peasant art. This stemmed from the late nineteenth-century patronage of artistic crafts and was gradually revived after the Revolution and the Civil War and again after the Second World War. ${ }^{119}$

A reference to folk art allowed not only functional structure and ornament to be reconciled ('construction' and 'composition') but also technical 
skill and 'artistic mystery', which was positively reconceptualised as 'fantasy'. Smirnov argued that fantasy, integral to everyday peasant life and art, serves for the development of a meaningful image, and so, say, an ornamental rooster is a means to provoke a festive mood and a signifier of certain typical features of peasant life. ${ }^{120}$ Thus, an ornament was justified as an essential element of enjoyable labour and a source of the consumer's positive emotions, and the 'folk wisdom', carefully mastered by professional applied artists, guaranteed the ornament's 'honesty'. In short, folk ornament was to be a measuring stick for an artist who struggled with the contradiction between pleasing the consumer and honestly revealing material and function.

Similarly, Saltykov, a connoisseur of folk art and ardent supporter of craft cooperatives in the traditional pottery region of Gzhel', maintained that folk ornament is 'deeply honest' and has nothing to do with the 'falsity and perversity of formalism'. ${ }^{121}$ However, like Smirnov, he warned applied artists against the literal adoption of folk art models. In the autumn of 1955, reviewing an exhibition of applied art from the Baltic republics, Saltykov specified that contemporary artists should not mechanically copy the forms and ornaments of folk art, but should always carefully adapt them to their contemporary context. Forms, ornamental compositions and even colour schemes of certain objects can become obsolete and irrelevant. What the contemporary artist should take from folk art is the deep structural principle of the coherence of all parts and the subjection of form to function. ${ }^{122}$ 'Soviet artists must learn from the [villagel folk to create simple and convenient things', advised the art historian Nikita Voronov, the son of the prominent specialist on folk art Vasilii Voronov (1887-1940), in a 1957 article in Dekorativnoe Iskusstvo SSSR. He believed that the heritage of peasant art should provide the solution of a 'burning' problem of expediency. ${ }^{123}$ Among the objects illustrating this proposition was a ceramic fruit set by the artist M. Levina, produced at the faience factory in the Kalinin (now Tver) region through a combination of manual and machine techniques. ${ }^{124}$ The set's plate and saucer are decorated by the technique of free-flowing glaze, which produces different patterns on each particular object. Thus, the ornament is the explicit trace of the industrial process of glazing; it tells the story of labour invested in the product.

The key to the successful translation of folk art principles into mass production was often found in a 'deep respect' for the material. ${ }^{125}$ Applied artists believed - or hoped - that material could not lie. 'Considering the material as the means of embodying the ideal conception of the work, Ian artistl should use its artistic and technological qualities to the utmost', Smirnov argued. He added that each material possesses inherent decorative qualities. Using his favourite example, glass, he explained: 'The main expressive qualities of glass [are achieved by] light: the refraction of light in facets; the condensation of light within glass; the free, almost unchang- 
ing, passage of light through glass; and the colouring of light through glass by almost any colour. ${ }^{126}$ Wood, textiles, ceramics, glass and plastics were expected to be treated skilfully, so that the best qualities of each material could be revealed. ${ }^{127}$

Plastic presents an especially interesting case of this line of thinking. As a new material, devoid of any history of artistic treatment, plastic provided a challenge to the decorative artist. In the same 1954 conference talk, Boris Smirnov suggested an approach to plastics that was at odds with the ideal of honesty. Since this material was still 'in its infancy', and its 'expressive aesthetic qualities' had not yet been found, it could be used as a cheaper replacement for gems, so beloved by Soviet people. One part of Smirnov's argument for democratising good taste was that if gems were not available for mass production as commodities, their beauty should be reproduced in plastic. Was this a call for imitation and the deception of the consumer? By no means, Smirnov explained, suggesting 'a sort of approximation of beautiful natural materials'. ${ }^{128}$ He explained the difference:

If you thoroughly copy the structure, for example, of such a material as malachite, imitating the characteristic articulation of its pattern, produced by the technique of composition from different cut plates of a rock, then you get either a quite expensive museum copy, or in the case of bad-quality work, merely ersatz in the worst sense of the word. However, you can masterfully give new expression to a beautiful material, proceeding from the specific possibilities of plastic. Create a new, more or less similar, pattern, keeping the characteristic green colour, or probably even changing it. Create a new, not less beautiful red or blue 'malachite' - actually, 'malachite' only by association. ${ }^{129}$

The gem as a creative reference point rather than as a model for falsification was Smirnov's peculiar scheme for what I would call 'honest imitation'. An object made of 'red malachite' was not meant to fool the consumer but to make them appreciate the skill and creativity of its maker.

The actual production of plastic commodities was, however, a far sight from Smirnov's ideal. In 1957 the Leningrad critic Virko Blek found that most plastic objects - such as baskets, plates and vases - produced by local industry were made with awful taste and overloaded with ornamentation. Blek argued that these plastics showed an extreme lack of respect for the material from which they were made. Unlike Smirnov, she urged artists to explore the inner qualities of this new medium: 'Plastic is one of the most perfect materials, harbouring broad opportunities. And here one should predominantly operate with line, colour, strict and restrained forms. I believe that complex forms and ornamentation are not appropriate for plastics. ${ }^{130}$ At the conference on the 'Problems of organising and maintaining the propaganda of visual arts in Leningrad' in March 1959, the critic Moisei Kagan commented on this subject more sharply: 'When [artists] try to hide the aesthetic qualities of new materials, being ashamed of these qualities, when these materials are used for faking traditional 
and precious ones - gold or silver, velvet or marble - the result is sheer tastelessness in the sphere of applied art.' ${ }^{131}$ His colleague B. A. Oleneva complained that objects that used to be produced from traditional materials look like cheap imitations when made from plastic. For this she blamed the directors of various small cooperatives (arteli $i$ artel'ki) in addition to the lack of proper technical equipment for processing plastics. ${ }^{132}$ Thus, 'the age of plastics', as Oleneva called her own time, made the task of producing 'honest' objects quite difficult. In the US and western Europe, plastic had acquired a dual reputation as both a super-modern material and an inferior substitute for more authentic materials by the 1960s. This was famously epitomised in popular culture by the film The Graduate (1967) and the song 'Substitute' by the rock band The Who. ${ }^{133}$ Unsurprisingly, given that the Soviet Union emulated Western examples, plastic could hardly be a truthful material, despite artists' and critics' attempts to reveal its 'hidden possibilities'. Yet these attempts, too, had Western precedents, which people such as Blek and Kagan might have well been aware of. For example, the Austrian-born British designer Gaby Schreiber had already argued in the early 1950s for the creation of new forms in plastic and against the simple imitation of the forms of traditional materials such as clay and metal. ${ }^{134}$ An even closer example for Soviet designers to emulate was the state-sponsored development of high-quality, plastic household goods in East Germany (which are often still remembered as symbols of German socialist consumer culture). ${ }^{135}$

From professional discussions and articles in Dekorativnoe Iskusstvo SSSR, the theme of honesty spread into popular advice literature. This theme was considered in a peculiar way in a 1960 book by the prominent art historian Nina Dmitrieva entitled On Beauty. The book presented a comprehensive explanation of Soviet aesthetics of that era and its practical applications. ${ }^{136}$ Dmitrieva insisted that the home of a modern person should be free of all things false and pretentious: no chairs where you cannot sit, no plates and dishes from which you never eat, no vases in which you cannot place flowers. Objects' functions should not just be honestly expressed but also fulfilled. This position recalls a recent argument made by the art critic Ekaterina Degot' regarding the 'non-market' aesthetics of Soviet goods. For Degot', 'Soviet things - in their ideal, rarely fulfilled variant - resist the aesthetics of "market appearance" and proceed straight to the essence of function: thick trousers make you warm, pasta feeds you, antiaircraft machine guns shoot'. ${ }^{137}$ However, if the 'unfashionable' and 'formless' objects that Degot' describes filled Soviet flats and still constitute part of post-Soviet collective memory of Soviet everyday life, they were not the ideal to which the 1950s design professionals aspired. Like many of her colleagues, Dmitrieva advocated a beauty that was understood as essential rather than superfluous. 'Everywhere in the domestic environment, beauty is inseparable from expediency', she main- 
tained. Functionality, expressed in an efficient material form, which corresponded to contemporary visual language, constituted the "non-market aesthetics' of Soviet objects in the late 1950s and early 1960s, not formlessness or awkwardness. In her advice, Dmitrieva endowed Soviet objects with moral, human characteristics and also with visual appeal: you do not have to 'struggle' or conflict with them; they do not 'oppress' you, but predict your 'wishes and needs'. ${ }^{138}$ Evidently, Dmitrieva understood these 'wishes and needs' as authentic and not imposed by any external force, and therefore easily met by simple, beautiful and useful goods.

Thus, the 'honest' socialist object was imagined at the intersection between functionalism and ornamentalism, beauty and utility, artists' aesthetic principles and consumers' preferences. Indeed, who would prefer dishonesty over honesty, especially if, as Smirnov, Dmitrieva and others believed, urban consumers were predisposed to honest beauty just like peasant craftspeople? The Soviet consumer was imagined as the designer's ally in the battle for good taste against the agents of dishonesty and kitsch - undereducated managers of factories and craft cooperatives, narrow-minded trade workers and the philistine instructors of amateur craft-making circles. ${ }^{139}$ This idealistic view culminated in the all-Union exhibition 'Art into Life' (Iskusstvo v byt) in April-June 1961. The event was sponsored by the Soviet Ministry of Culture, the Academy of Arts and the Unions of Artists and Architects and held in the Moscow Central Exhibition Hall (Manege). The exhibition aimed to showcase the best models of household goods for mass production - from furniture to glass - produced at factories across the Soviet Union, as well as model interiors for prefabricated flats. Design professionals optimistically viewed it as the beginning of a radical transformation of the mass production of household goods and the enhancement of their role as advisors to industry and arbiters of public taste. The scope, diversity and quality of the exhibits signified the triumph of art that was oriented towards mass production and the satisfaction of consumer needs. One reviewer enthusiastically noted that 'simple household objects' were exhibited alongside objects traditionally ascribed to applied art (such as porcelain cups or glass vases). ${ }^{140}$ Aluminium and enamelled kitchenware produced at two Leningrad factories ${ }^{141}$ was juxtaposed with a modestly decorated porcelain tea set from the Leningrad Porcelain Factory as embodiments of honest artistic labour. Glassware from Moscow and Moscow oblast, Leningrad and Byarozowka (Belarus), and highly praised Lithuanian furniture were perhaps the most obviously 'honest' items on display, as the light that played through the glass (as discussed by Smirnov) and the texture and structure of the bare wood produced a strong aesthetic effect. Above all, the exhibition was arranged in an 'honest' way: the designers A. Vilup and M. Plees were complimented for achieving 'maximal simplicity and clarity' and the avoidance of 'spectacular techniques' and 'deliberate embellishment'. ${ }^{142}$ 


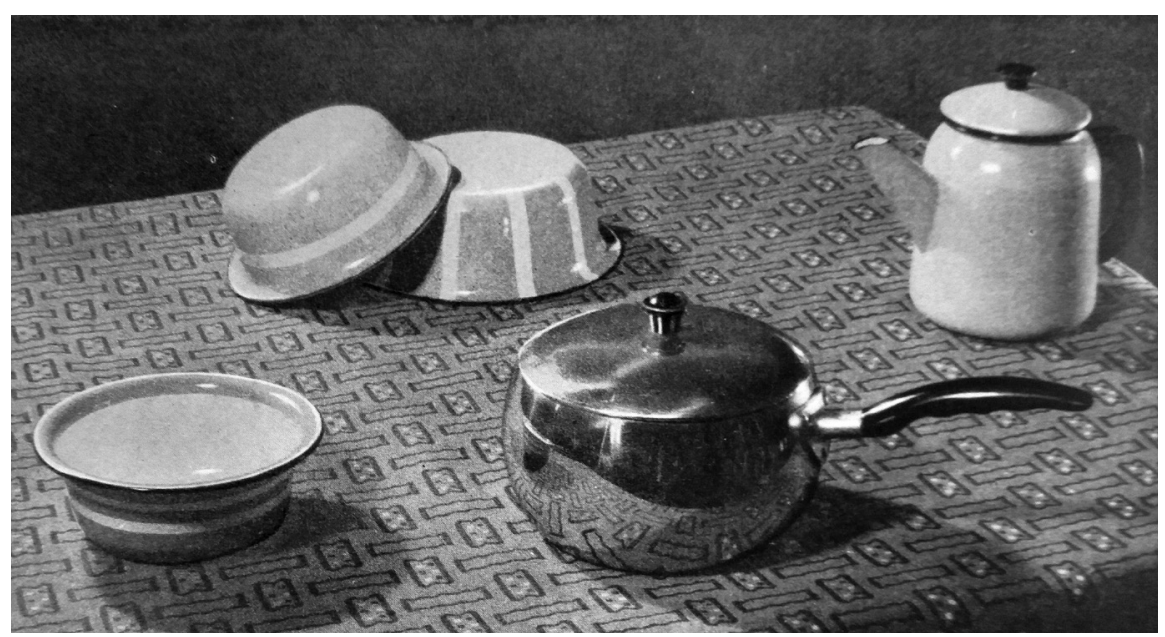

All rights reserved and permission to use the figure must be obtained from the copyright holder.

\subsection{Kitchenware, before 1961.}

For the agents of the aesthetic turn, the exhibition was evidence that the Soviet artist was becoming fully integrated into industrial production and that art and everyday life were becoming unified. The choice of a productivist slogan as the title for the exhibition was no coincidence. The exhibition manifested the concept of Soviet design-as-practice ( $k h u^{-}$ dozhestvennoe konstruirovanie, 'artistic engineering') and its profound impact upon applied art in terms of the relation to industry. As the applied artist I. Chizhova commented seven years later, "it seemed that the paths of khudozhestvennoe konstruirovanie and applied art are converging, and this is the only possible way to further the creation of objects for people, first and foremost, rational in form, convenient and beautiful'. ${ }^{143}$ However, as viewers and design professionals themselves complained, the majority of the exhibits were still unique objects rather than samples of already mass-produced goods. ${ }^{144}$ While a newsreel about the exhibition in 1962 presented the visitors' criticisms as minor and stemming from a general curiosity and excitement with the new, ${ }^{145}$ the responses in guest books, as Susan Reid demonstrated in her study, ${ }^{146}$ were far from uniformly enthusiastic. Evidently, taste hierarchies as imagined by design professionals (socialist honesty vs. petty-bourgeois excess and/or capitalist ultrafashionable functionalism) could hardly reflect social reality.

\section{Conclusion}

This chapter has offered a view of post-war Soviet design in a broad sense, not reducible to genealogies of institutions, biographies of professionals, or a stylistic evolution from socialist realism to socialist modernism. It 
mapped the space of numerous ideas, activities and objects. Or, to use the terms of Régis Debray, ${ }^{147}$ it analysed the 'mediological' basis for different creative activities that intensified, or emerged, after Stalin's death. The development of each of the three major aesthetic categories - (socialist) realism, contemporaneity and taste - followed a similar path from a cautious evasion of the orthodoxies set by easel art through the appeal to folk tradition, to a decisive embrace of functionalism stimulated by unprecedented architectural reform. By the early 1960s, the time of the institutionalisation of industrial design, design professionals had developed a number of visions of and requirements for socialist objects that often conflicted. A vibrant, up-to-date and honest object was to become a strong material argument for the advantages of state socialism. The following chapters consider the practical attempts to make socialism tangible and enjoyable.

\section{Notes}

1 'Da zdravstvuet slavnoe 50-letiie Velikoi Oktiabr'skoi sotsialisticheskoi revoliutsii!', Dekrativnoe Iskusstvo SSSR 10 (1967), 1-2.

2 Pulegoso (from the Italian dialect word pulega, 'bubble') refers to glass containing numerous bubbles of various sizes, produced by adding bicarbonate of soda, gasoline or other substances to the melt. The technique was elaborated in the late 1920s at Murano by designer and businessman Napoleone Martinuzzi. The irregular texture of the glass produced by the bubbles resonated with Soviet glass artists' experimentation with textures in the 1960s; hence the popularity of pulegoso in the Soviet Union.

3 Jacques Rancière, 'Foreword', in The Politics of Aesthetics: The Distribution of the Sensible (London: Continuum, 2006), p. 10.

4 Jacques Rancière, 'Artistic Regimes and the Shortcomings of the Notion of Modernity', in The Politics of Aesthetics, p. 21.

5 Boris Groys, The Total Art of Stalinism: Avant-garde, Aesthetic Dictatorship, and Beyond (Princeton, NJ: Princeton University Press, 1992).

6 Matthew Cullerne Bown, Socialist Realist Painting (New Haven, CT: Yale University Press, 1998).

7 On Deyneka, see Bown, Socialist Realist Painting; Christina Kiaer, 'Was Socialist Realism Forced Labour? The Case of Alexander Deineka in the 1930s', Oxford Art Journal 28.3 (2005), 321-45, doi:10.1093/oxartj/kci031. On Laktionov, see Susan E. Reid, 'Modernizing Socialist Realism in the Khrushchev Thaw: The Struggle for a "Contemporary Style" in Soviet Art', in Polly Jones (ed.), The Dilemmas of De-Stalinization: Negotiating Cultural and Social Change in the Khrushchev Era (London: Routledge, 2006), pp. 209-30.

8 From Andrei Zhdanov's formulation at the First All-Union Congress of Soviet Writers in August 1934. 'Pervyi Vsesoiuznyi S"ezd sovetskikh pisatelei. Stenograficheskii otchet' (Moscow, 1934), p. 175. Quoted in Igor Golomshtok, Totalitarnoe iskusstvo (Moscow: Gallart, 1994), p. 86.

9 Reid, 'Khrushchev Modern'.

10 TsGALI SPb, f. 78, op. 4, d. 533, l. 5.

11 For extensive historical analysis of the role of materiality and symbolism of glass in Russian culture, see Julia Bekman Chadaga, Optical Play: Glass, Vision, and Spectacle in Russian Culture (Evanston, IL: Northwestern University Press, 2014).

12 TsGALI SPb, f. 78, op. 4, d.533, 1. 5. 
13 Aleksandr Saltykov, 'Voprosy razvitiia dekorativno-prikladnogo iskusstva', Iskusstvo 2 (1955), 30.

14 Ibid., 31.

15 Moisei Kagan, 'O spetsifike i sushchnosti prikladnogo iskusstva', Iskusstvo 1 (1956), 16-21.

16 Kagan, 'O spetsifike i sushchnosti', 17-18.

17 TsGALI SPb, f. 78, op. 4, d. 390, 1. 14.

18 TsGALI SPb, f. 78, op. 4, d. 390, ll. 22-9.

19 TsGALI SPb, f. 78, op. 4, d. 390, 1. 32.

20 TsGALI SPb, f. 78, op. 4, d. 390, 1. 90.

21 TsGALI SPb, f. 78, op. 4, d. 390, 1. 107.

22 Here Chekalov demonstrates the very 'terminological confusion' that so upset Kagan: he uses 'decorative' and 'applied' interchangeably.

23 RGALI, f. 2943, op. 1, d. 2550, 1. 2.

24 RGALI, f. 2943 , op. 1, d. $2550,1.4$.

25 RGALI, f. 2943, op. 1, d. 2550, 1. 3.

26 For example, 'Sovetskoe izobrazitel'noe iskusstvo v 1952 godu. O Vsesoiuznoi khudozhestvennoi vystavke', Iskusstvo 1 (1953), 3-4; TsGALI SPb, f. 78, op. 4, d. 435.

27 RGALI, f. 2943, op. 1, d. 2550, 1. 5.

28 RGALI, f. 2943, op. 1, d. 2550, ll. 5-6.

29 Karl Marx, Writings of the Young Marx on Philosophy and Society (Indianapolis, IN: Hackett Publishing, 1997), p. 293.

30 RGALI, f. 2943, op. 1, d. 2550, 1. 8.

31 RGALI, f. 2943 , op. 1, d. $2550,1.9$.

32 RGALI, f. 2943, op. 1, d. 2550, 1. 19.

33 RGALI, f. 2943, op. 1, d. 2550, 1. 21.

34 RGALI, f. 2943, op. 1, d. 2550, ll. 14-15

35 Nikolai Punin, 'Pamiatnik III Internatsionala', in Irina Punina and Vasilii Rakitin (eds), Nikolai Punin. O Tatline (Moscow: RA, 1994), p. 20.

36 In light of the resonances with Wilhelm Röntgen's experiments in Russia, the iron frame could be associated with the skeleton. As Olga Matich and John E. Bowlt argue, 'the artists of the avant-garde were fascinated to discover mechanical parallels between zoological structures made clear with the X-ray and the industrial frames of the new iron buildings towering above Moscow and St. Petersburg'. John E. Bowlt and Olga Matich, 'Introduction', in John E. Bowlt and Olga Matich (eds), Laboratory of Dreams: The Russian Avant-garde and Cultural Experiment (Stanford, CA: Stanford University Press, 1996), p. 12.

37 RGALI, f. 2943, op. 1, d. 2550, 1. 10.

38 RGALI, f. 2943, op. 1, d. 2550, 1. 28.

39 RGALI, f. 2943, op. 1, d. 2550, 1. 30-1.

40 Susan E. Reid, 'Art of Socialist Countries, Moscow 1958-59, and the Contemporary Style of Painting', in Susan E. Reid and David Crowley (eds), Style and Socialism: Modernity and Material Culture in Post-War Eastern Europe (Oxford: Berg, 2000), pp. 101-32.

41 RGALI, f. 2943, op. 1, d. 2550, 1l. 45-7. Nazarevskaya's creative biography is discussed in Maria Blumin, 'Vliianiie iskusstva avangarga na ornamental'nye motivy tkanei 1910-kh-1939-kh godov: na promere stran Zapadnoi Evropy i Rossii', PhD dissertation, St Petersburg State Academy of Art and Industry, 2006; summary available at www.dissercat.com/content/vliyanie-iskusstva-avangarda-na-ornamen talnye-motivy-tkanei-1910-1930-kh-godov-na-primere-st, (accessed 8 November 2011).

42 RGALI, f. 2943, op. 1, d. 2550, l. 57.

43 RGALI, f. 2943, op. 1, d. 2550, 1. 78. 
44 Bennett, Vibrant Matter.

45 The exhibition was co-curated by Jane Pavitt and David Crowley. According to Pavitt, it was quite difficult to convince the administration of the V\&A to open the exhibition with such a provocative title (Jane Pavitt, 'Cold War Modern: Design 1945-70’, public lecture, Open Society Archives, Budapest, 4 October 2013). See the catalogue of the exhibition: David Crowley and Jane Pavitt (eds), Cold War Modern: Design 1945-70 (London: V\&A Publishing, 2008).

46 Reid, 'Khrushchev Modern'.

47 This understanding appears, more or less explicitly, in the work of many critics and scholars of the twentieth century, most famously Walter Benjamin. On modernism's critical aspect as related to material culture, see Brown, Things.

48 Tom Cubbin, 'From Technocracy to Techno-Utopia: Futurology and the Soviet Home at VNIITE, 1964-1974', MA dissertation, Royal College of Arts, 2012.

49 Brown, Things, p. 16.

50 Ibid., p. 15.

51 Notably, Brown considers Constructivism and Surrealism as two conscious attempts 'to achieve greater intimacy with things and to exert a different determination for them'. Brown, Things, p. 11.

52 Arvatov, 'Byt i kul'tura veshchi', pp. 72-5. Quotes are taken from Christina Kiaer's translation: Boris Arvatov and Christina Kiaer, 'Everyday Life and the Culture of the Thing (Toward the Formulation of the Question)', October 81 (1997), 119-28, doi:10.2307/779022.

53 Arvatov and Kiaer, 'Everyday Life and the Culture of the Thing', 126.

54 The concern with the affective components of objects, characteristic of Arvatov's theory and of the Russian avant-garde in general, was taken by Sergei Oushakine as the starting point for a new scholarly trend, which he calls 'the materiology of emotions'. The landmark event for this trend was the interdisciplinary conference 'Objects of Affection: Towards the Materiology of Emotions', Princeton University, 4-6 May 2012, http://objectsofaffection.wordpress.com/about/. Selected presentations from this conference constituted a section of Russian scholarly journal New Literary Observer in 2013. See Oushakine, 'Dinamiziruiushchaia veshch'.

55 M. V. Fokina et al. (eds), Stranitsy istorii iunykh lenintsev (materialy dlia besed) (Moscow: Kniga po trebovaniiu, 1976), pp. 71-2.

56 Bocharnikova, 'Inventing Socialist Modern', pp. 115-54, 198-205.

57 Susan E. Reid, 'Khrushchev's Children Paradise: The Pioneer Palace, Moscow, 1958-62', in David Crowley and Susan E. Reid, Socialist Spaces: Sites of Everyday Life in the Eastern Bloc (Oxford: Bloomsbury, 2002), pp. 154-6.

58 Sarah Williams Goldhagen and Rejean Legault, 'Introduction: Critical Themes of Postwar Modernism', in Sarah Williams Goldhagen and Rejean Legault (eds), Anxious Modernisms: Experimentation in Postwar Architectural Culture (Cambridge, MA: MIT Press, 2001), p. 22.

59 Viktor Egerev et al., Moskovskii dvorets pionerov (Moscow: Izdatel'stvo literatury po stroitel'stvu, 1964), pp. 5-19.

60 It should be noted that attitudes to functionalism differed among the architects of the modern movement, and not all of them even had functionalist intentions. See Stanford Anderson, 'The Fiction of Function', Assemblage 2 (1987), 18, doi:10.2307/3171086.

61 On 24 December 1958 the Supreme Soviet of the USSR accepted a statute 'On Strengthening the Connection of School with Life and Further Development of the System of People's Education', aimed at global-scale training of technically competent personnel for industry and agriculture. According to this, only eight years of secondary school education were mandatory, after which students could either enter vocational schools or study for three more years in high school, where two days a week would be scheduled for internship at industrial or agricultural 
enterprises. School graduates received a certificate of technical proficiency. 'Ob ukrupnenii sviazi shkoly s zhisniu i dal'neishem razvitii sistemy narodnogo obrazovaniia', in A. A. Abakumov et al. (eds), Narodnoe obrazovaniie $v$ SSSR. Obshcheobrazovatel'naia shkola. Sbornik dokumentov. 1917-1973 (Moscow: Pedagogika, 1974), pp. 53-61. The lack of positions for school interns in industry impeded the successful realisation of this reform, and in the mid-1960s it was curtailed. 'Priniat zakon "Ob ukrupnenii sviazi shkoly s zhisniu I dal'neishem razvitii sistemy narodnogo obrazovaniia", the website of the B. N. Eltsin Presidential Library, www.prlib.ru/History/Pages/Item.aspx?itemid=365 (accessed 18 December 2014). For a detailed account of Khrushchev's educational reform, see Laurent Caumel, 'The Scientist, the Pedagogue and the Party Official: Interest Groups, Public Opinion and Decision-Making in the 1958 Education Reform', in Ilic and Smith (eds), Soviet State and Society under Nikita Khrushchev, pp. 66-85.

62 'O formakh i srokakh obucheniia v vysshykh uchebnykh zavedeniiakh i o proizvodstvennoi praktike studentov', resolution by the USSR Council of Ministers, 4 August 1959, http://base.consultant.ru/cons/cgi/online.cgi?req=doc;base=ESU;n= 9934 (accessed 18 November 2014).

63 RGALI, f. 2466 op. 2 d. 137, 1. 12.

64 RGALI, f. 2460 , op. 2, d. 1167; RGALI, f. 2460, op. 2, d. 1168. According to this source, out of thirty-four diploma works defended in June 1960 by students of the metalwork section, five were dedicated to the palace. In the carpentry section, the percentage was even higher: eleven of twenty-one.

65 Khan-Magomedov, Pionery sovetskogo dizaina, p. 366. Khan-Magomedov argues that the department of carpentry and metalwork most fully responded to the initial programme of Vkhutemas that was stated in the decree by the Council of People's Commissars from 25 December 1920. This programme aimed, essentially, at educating specialists to raise the quality of the industrial production of useful objects. The text of the decree was published in Izvestiia, 25 December 1920, p. 1.

66 Varst (Vasvara Stepanova), 'O rabotakh konstruktivistskoi molodezhi', LEF 3 (1923), 53.

67 Arvatov and Kiaer, 'Everyday Life and the Culture of the Thing', 126.

68 This is the term used by Selim Khan-Magomedov as the title of his seminal 1995 book, with a clear allusion to Nikolaus Pevsner's famous work Pioneers of the Modern Movement: From William Morris to Walter Gropius (London: Faber \& Faber, 1936).

69 A. Abramova, 'Naslediie Vkhutemasa', Dekorativnoe Iskusstvo SSSR 4 (1964), 8-12; Khan-Magomedov, Pionery sovetskogo dizaina, pp. 383-99.

70 RGALI, f. 2460, op. 2, d. 1167, 1. 131.

71 Students of both departments in many cases designed similar objects - furniture - and worked with similar materials - tubular steel, plastic and wood in different combination. This reveals the problematic nature of institutional division according to the materials processed rather than the products designed. The necessity of uniting industrial designers in one section, distinguishing them from sculptors and decorators working with similar materials, would soon be realised at the governmental level. This problem was realised by the MVKhPU administration in the 1960s, and during this decade the disciplinary division was several times restructured. In particular, in 1965 the carpentry section was transformed into the department of furniture and transferred into the department of interior and equipment, while a special section for 'artistic engineering' (the term used for industrial design) was organised on the basis of the metalwork section. RGALI, f. 2460, introduction to op. 2.

72 Harris, Communism on Tomorrow Street, pp. 231-7.

73 N. Orieva, 'Krasota truda', Tekhnika - Molodezhi 7 (1960), 4. On the criticism of old furniture types, see V. Dele, 'O sovremennot mebeli', Dekorativnoe Iskusstvo SSSR 5 (1958), 28-32. 
74 RGALI, f. 2460, op. 2, d. 1168, ll. 127-33.

75 RGALI, f. 2460, op. 2, d. 1168, ll. 46-53.

76 RGALI, f. 2460, op. 2, d. 1168, l. 125.

77 RGALI, f. 2460, op. 2, d. 1168, ll. 36-44.

78 RGALI, f. 2460, op. 2, d. 1168, ll. 231-3.

79 Charles S. Peirce, The Philosophy of Peirce: Selected Writings (London: Routledge and Kegan Paul, 1950), pp. 101-15.

80 Krisztina Fehérváry, Politics in Color and Concrete: Socialist Materialities and the Middle Class in Hungary (Bloomington, IN: Indiana University Press, 2013), pp. 7-8.

81 RGALI, f. 2460, op. 2, d. 1168, ll. 89-91.

82 RGALI, f. 2460, op. 2, d. 1168, 1. 92.

83 RGALI, f. 2460, op. 2, d. 1168, ll. 198-206.

84 E. Koridalina, 'Oni zdes' khoziaeva', Semia i shkola 4 (1962), 9-10; Reid, 'Khrushchev's Children Paradise'.

85 Goldhagen and Legault, 'Introduction', p. 19. Several essays from this volume deal specifically with the theme of homo ludens as related to architecture.

86 RGALI, f. 2460, op. 2, d. 1167, 1. 131

87 RGALI, f. 2460, op. 2, d. 1168, 1. 160.

88 RGALI, f. 2466, op. 2, d. 137.

89 In 1960 there was no special law concerning industrial standards in the USSR. The 1924 resolution of the Central Executive Committee and the Council of People's Commissars 'On industrial standards' (drawings and models) was invalidated in 1936. No replacement document was issued. Technical drawings were now protected by copyright law, while models (prototypes) fell under the category 'technical improvements' and were protected by the 1931 regulation on inventions and technical improvements, according to which 'author licence', rather than patents, became the main form of protecting the rights of inventors. Evidently, student projects, drawings as well as models, were not considered as belonging to either of these categories, because they were ultimately not admitted into industrial production and thus not given author licences. A. P. Sergeev, Pravo intellektual'noi sobstvennosti v Rossiiskoi Federatsii (Moscow: Prospekt, 2003), pp. 34-48.

90 Egerev et al., Moskovskii dvorets pionerov, p. 35.

91 Ibid., p. 94.

92 E. Bruskova and S. Soloveichik, 'Kliuch ot strany romantikov', Komsomol'skaia Pravda, 2 June 1962, pp. 1-2. Notably, one of the article's authors, Simon Soloveichik, initiated the liberal trend in upbringing, based on tolerance to children's initiative. See Catriona Kelly, Children's World: Growing Up in Russia, 1890-1991 (New Haven, CT: Yale University Press, 2007), p. 388.

93 Egerev et al., Moskovskii dvorets pionerov, p. 32.

94 On the attitude of architectural experts and the broader educated public in Russia to this building today, see 'Arkhitektura ot Stalina do Khrushcheva'; 'Iurii Bolotov - o tom, pochemu Dvorets Pionerov - samoe luchshee mesto v Moskve', 16 November 2014, www.the-village.ru/village/city/modern-architecture/169531-dvorets-pionerov-na-vorobievyh (accessed 18 November 2014).

95 RGALI, f. 2943, op. 2, d. 82, 1. 6.

96 Vasilii Shukshin, Zhivet takoi paren' (Kinosdudiia imeni M. Gor'kogo, 1962), www.youtube.com/watch?v=mGLgp6AP1gQ (accessed 31 May 2014). The role of Pashka was played by Leonid Kuravlev.

97 This understanding of taste is mostly associated with fin-de-siècle studies by two prominent sociologists: the American Thorstein Veblen and the German Georg Simmel. See, for example, Donald N. Levine (ed.), Georg Simmel on Individuality and Social Forms (Chicago: University of Chicago Press, 1972); Thorstein Veblen and C. Wright Mills, The Theory of the Leisure Class (New Brunswick, NJ: Transaction 
Publishers, 1992). The theme of taste, along with manners, was famously treated in 1939 by the German sociologist Norbert Elias in his seminal book on the cultural and political development of European society, later published in English as The Civilizing Process: The History of Manners (New York: Urizen Books, 1978). Taste prominently appeared in post-war American sociology as an element of consumption and mass culture; see particularly David Riesman, The Lonely Crowd: A Study of the Changing American Character (New York: Doubleday, 1953); Herbert J. Gans, Popular Culture and High Culture: An Analysis and Evaluation of Taste (New York: Basic Books, 1999). A classic sociological study of taste is the 1979 book by Pierre Bourdieu, Distinction: A Social Critique of the Judgement of Taste (London: Routledge, 1992), which, though confined to the specificities of French society, became a theoretical inspiration for a number of studies. In particular, Bourdieu's vision of taste as a manifestation of class distinction was drawn on and also criticised in the 1980s and 1990s by anthropologists concerned with material culture and consumption: Miller, Material Culture and Mass Consumption, pp. 147-217, 106-25.

98 Bourdieu, Distinction, p. 173.

99 Ibid., p. 227.

100 Pevsner, Pioneers of Modern Design, p. 21.

101 Max Horkheimer and Theodor W. Adorno, 'The Culture Industry: Enlightenment as Mass Deception', in Max Horkheimer and Theodor W. Adorno, Dialectic of Enlightenment: Philosophical Fragments (Stanford, CA: Stanford University Press, 2002), pp. 94-136; Guy Debord, The Society of the Spectacle (New York: Zone Books, 1995).

102 Kristin Roth-Ey, Moscow Prime Time: How the Soviet Union Built the Media Empire That Lost the Cultural Cold War (Ithaca, NY: Cornell University Press, 2011), p. 2.

103 Stephen Lovell, The Russian Reading Revolution: Print Culture in the Soviet and Post-Soviet Eras (Basingstoke: Macmillan, 2000), pp. 15-21.

104 Bourdieu, Distinction, p. 56.

105 Osip Brik, 'V Proizvodstvo!', LEF 1 (1923), 105.

106 Komsomol'skaia Pravda, 4 November 1928, quoted in Svetlana Boym, Common Places: Mythologies of Everyday Life in Russia (Cambridge, MA: Harvard University Press, 1994). The quotation is translated by Boym.

107 Gronow, Caviar with Champagne; Hessler, A Social History of Soviet Trade; Randall, The Soviet Dream World of Retail Trade and Consumption in the 1930s.

108 Susan J. Linz (ed.), The Impact of World War II on the Soviet Union (Totowa, NJ: Rowman and Allanheld, 1985); Vera S. Dunham, In Stalin's Time: Middleclass Values in Soviet Fiction (Durham, NC: Duke University Press, 1990), pp. 3-18; E. IU Zubkova, Russia after the War: Hopes, Illusions, and Disappointments, 1945-1957 (Armonk, NY: M.E. Sharpe, 1998), pp. 31-56, 101-8.

109 Jeffrey W. Jones, Everyday Life and the 'Reconstruction' of Soviet Russia during and after the Great Patriotic War, 1943-1948 (Bloomington, IN: Slavica Publishers, 2008), pp. 180-212.

110 Dunham, In Stalin's Time.

111 Chauncy D. Harris, 'Urbanization and Population Growth in the Soviet Union, 1959-1970', Geographical Review 61.1 (1971), 102-24, doi:10.2307/213369; Harris, Communism on Tomorrow Street.

112 Iurii Gerchuk argues that the critique of architectural excess by Khrushchev and a number of high-ranking architects brought 'radical aesthetic consequences' that affected decorative art. Iurii Gerchuk, Krovoizliianiie $v$ MOSKh, ili Khrushchev v Manezhe (Moscow: Novoe Literaturnoe Obozreniie, 2008), p. 13.

113 This urge was both expressed and further stimulated by the series of essays by Vladimir Pomerantsev, entitled 'On Sincerity in Literature', published in the leading literary journal Novy mir in December 1953. V. M. Pomerantsev, 'Ob 
iskrennosti v literature', Novyi mir 12 (1953), 218-19. For the meanings of truth and sincerity in post-Stalin intellectual milieus and broader public culture, see Zubkova, Russia after the War; V. M. Zubok, Zhivago's Children: The Last Russian Intelligentsia (Cambridge, MA: Belknap Press of Harvard University Press, 2011). In a non-scholarly but essayistic manner, the issue of the 'search for deep truth' in the 1960s is considered in a book by two writers who reckon themselves among the shestidiesiatniki ('people of the 1960s'): Aleksandr Genis and Piotr Vail', 60-e: mir sovetskogo cheloveka (Ann Arbor, MI: Ardis, 1988).

114 Aleksandr Saltykov, 'O khudozhestvennom kachestve promyshlennykh tovarov', Sovetskaia Torgovlia 9 (1954), 22.

115 Aleksandr Saltykov, 'Voprosy razvitiia dekorativno-prikladnogo iskusstva', Iskusstvo 2 (1955), 30-2.

116 Ibid.

117 The debates on the nature of composition and construction were held at the Institute of Artistic Culture (Inkhuk) in January-May 1921. While the participants in this debate held diverse opinions, a particularly strong voice came from those who saw composition as an arbitrary combination of elements, depending on an artist's subjective vision, and construction as an essential and clear basis for an artwork, an architectural edifice or a useful object. For example, Aleksandr Rodchenko defined construction as the only possible expression of an artist's concrete aim, while composition had been a symptom of the aimless art of the past; he also compared construction to the organisation of politics and social life in Soviet Russia. ("Protokol no.9 of 1/1-1921 g. Rabochaia gruppa ob"ektivnogo analiza Inkhuka. Analiz poniatii konstruktsiia i kompozitsiia i moment ikh razgranizheniia', private archive.) At another session, Varvara Stepanova stressed the 'tremendous distinction' between composition and construction: if the former is based on superfluity, the latter is devoid of excessive materials and elements. (Zasedaniie sektsii otdel'nykh iskusstv Inkhuka 25 ianvaria 1931 g. prot. no.22. Analiz poniatii konstruktsiia i kompozitsiia i moment ikh razgranizheniia (prodolzheniie)', private archive; copies of both documents were provided courtesy of Serguei Oushakine.) The results of this debate were a decisive factor for the development of Constructivism as the movement for integrating art into industrial production and social policy. Like the 1950s discussion of the 'honest object', the composition-construction debate can be interpreted as the search for symbolic order in a situation of social and political turmoil and change. The debate has been analysed in a number of scholarly works. For a concise analysis, see Christina Lodder, Russian Contructivism (New Haven, CT: Yale University Press, 1985). For a more detailed discussion, based on newly available archival documents, see Gough, The Artist as Producer.

118 TsGALI SPb, f. 266, op. 1, d. 291, 1l. 72-89.

119 Sergei Temerin, 'Izucheniie dekorativnogo iskusstva v sovetskom iskusstvoznanii za 40 let', Dekorativnoe Iskusstvo SSSR 1 (1958), 30-6; Richard Stites, 'Anti-iconoclasm', in Richard Stites, Revolutionary Dreams: Utopian Vision and Experimental Life in the Russian Revolution (Oxford: Oxford University Press, 1989), pp. 76-8; Gusarova, 'Leningradskaia keramika', pp. 49-51. Though certain craft cooperatives received the support of art historians and were able to raise the artistic quality of their production (the most prominent example is Aleksandr Saltykov's work for pottery cooperatives in Gzhel'), many others were still poorly equipped and managed in the late 1960s, to a great extent because they had to subsume to general management and planning guidelines and wage norms set by the Central Council for Industrial Cooperatives. Russian State Archive of Modern History, Moscow (hereafter RGANI), f. 5 op. 36 d. 48, ll. 103-6.

120 TsGALI SPb, f. 266, op. 1, d. 291, 1. 81.

121 Saltykov, 'Voprosy razvitiia dekorativno-prikladnogo iskusstva', 32. 
122 Aleksandr Saltykov, 'Prikladnoe iskusstvo trekh respublik (o vystavke proizvedenii khudozhnikov Latvii, Litvy i Estonii', Iskusstvo 6 (1955), 12.

123 Nikita Voronov, 'Narodnye traditsii I sovremennoe iskusstvo', Dekorativnoe Iskusstvo SSSR 1 (1958), 9. [AQ 1957 in text]

124 Ibid.

125 An expression used by Aleksei Balashov, head of the LSSKh section of decorative-applied art, at a meeting devoted to the discussion of Estonian applied art, 16 April 1954. TsGALI SPb, f. 78, op. 4, d. 287, 1. 63.

126 TsGALI SPb, f. 266 op. 1, d. 291, 1. 82.

127 TsGALI SPb, f. 78, op. 4, d. 287, 1. 56.

128 TsGALI SPb, f. 266, op. 1, d. 291, 1. 88.

129 TsGALI SPb, f. 266, op. 1, d. 291.

130 TsGALI SPb, f. 78, op. 4, d. 517, 1. 6.

131 TsGALI SPb, f. 78, op. 4, d. 46, 1. 11.

132 TsGALI SPb, f. 78, op. 4, d. 46, 1l. 85-6.

133 Susannah Handley, Nylon: The Story of a Fashion Revolution. A Celebration of Design from Art Silk to Nylon and Thinking Fibres (Baltimore, MD: Johns Hopkins University Press, 2000).

134 'Flying Colours', Design 152 (1961), 66-7.

135 Eli Rubin, Synthetic Socialism: Plastics and Dictatorship in the German Democratic Republic (Chapel Hill, NC: University of North Carolina Press, 2009).

136 Nina Dmitrieva, O prekrasnom (Moscow: Iskusstvo, 1960).

137 Degot', 'Ot tovara k tovarishchu', 37.

138 Dmitrieva, O prekrasnom, p. 69.

139 Amateur craft-making circles (kruzhki samodeiatel'nosti) were encouraged in Soviet Russia, at least in big urban centres, after the restructuring of artistic organisations in 1932. In this year the sector of amateur art was opened in the newly founded Moscow Regional Union of Soviet Artists (MOSSKh) (RGALI, f. 2943, op. 1, 1. 32). In 1953 the USSR Ministry of Culture allocated 90,000 roubles for maintaining amateur circles in the Russian Soviet Republic (RGAE, f. 7733 op. 42 d. 1152, 1. 30). In Leningrad, by 1954 every House of Culture included a studio of knitting, open to visitors (TsGALI SPb, f. 78, op. 4, d. 287, 1. 39). The popularity of these circles impelled professional artists to take control of their activity, which was perceived as potentially damaging to mass taste, since the circles' instructors often lacked special artistic education. This problem was often discussed in gender terms, since 'housewives' were reported to constitute the majority of the circles' attendees. RGALI, f. 2943, op. 1, d. 2477, 1. 52.

140 'Iskusstvo v byt', Dekorativnoe Iskusstvo SSSR 6 (1961), 5.

141 This same kitchenware was considered out-of-date by the employees of Leningrad VNIITE and was to be replaced by rational models, designed in 1965-66, as discussed in Chapter 3.

142 O. Baiar, 'Krasivoe v prostom', Dekorativnoe Iskusstvo SSSR 7 (1961), 1-6.

143 TsGALI SPb, f. 78, op. 5, d. 413, l. 10.

144 'Iskusstvo v byt'.

145 Sergei Gurov, 'Dlia vashego doma' (Central Red Banner Studio of Documentary Films, 1962), Russian State Archive of Cine-Photo Documents, Moscow (hereafter RGAKFD), d. 18199.

146 Reid, 'Khrushchev Modern', 227-68.

147 Régis Debray, 'Socialism: A Life-Cycle', New Left Review 2.46 (2007), 5-28. 